\title{
E-Ticaret Pazaryerlerine Yönelik Müşteri E-Sadakati: E-Güven ve E-Memnuniyetin Rolü
}

\author{
Büşra KUTLU KARABIYIK*
}

\author{
Geliş Tarihi (Received): 24.03.2021- Kabul Tarihi (Accepted): 27.09.2021
}

\section{$\ddot{\mathbf{O} z}$}

İşletmeden tüketiciye e-ticaret, tüketicilerin internet vasıtasıyla işletmelerden doğrudan mal ve hizmet satın alabilmeleri anlamına gelmektedir. Tüketiciler çevrimiçi ortamda çok sayıda alternatife kısa bir sürede ulaşabilmektedirler. Alternatiflerin fazlalılığı e-ticaret işletmelerinin sadakatli müssterilere ulaşmalarını zorlaştırmaktadır. Potansiyel müşterilerin farklı bir e-ticaret web sitesine yönelmeden, ihtiyaç duydukları ürün ve hizmetleri her zaman tercih ettikleri belirli bir e-ticaret web sitesinden alma eğilimlerine müşteri e-sadakati denilmektedir. E-sadakati sağlamış olan işlemelerde aynı müşterilerin devamlı ve yüksek miktardaki harcamaları işletme maliyetlerinin karşılanmasını kolaylaştırmaktadır. $\mathrm{Bu}$ çalışmada müşterilerin e-ticaret pazaryerlerine (trendyol, hepsiburada, n11, gittigidiyor, amazon, akakçe vb.) yönelik sadakatine etki eden faktörlerin araştırılması amaçlanmıştır. Çalışmada veri toplama aracı olarak anket yöntemi kullanılmıştır. 400 kişi ile gerçekleştirilen bu araştırmada e-güven ve ememnuniyetin e-sadakat üzerinde anlamlı ve pozitif etkilerinin olduğu bulunmuştur. Ayrıca e-güvene, e-memnuniyete ve dolaylı olarak e-sadakate etki eden diğer faktörler ortaya konulmuştur. Elde edilen bulgular neticesinde e-ticaret pazaryerlerinin müşteri e-sadakati oluşturabilmek için söz konusu faktörleri dikkate alarak yeni stratejiler yaratmaları beklenmektedir.

Anahtar Kelimeler: e-ticaret, e-ticaret pazaryeri, e-güven, e-memnuniyet, e-sadakat

\section{Customer E-Loyalty for E-Commerce Marketplaces:}

\section{The Role of E-Trust and E-Satisfaction}

\begin{abstract}
Business-to-consumer e-commerce means that consumers can directly purchase goods and services from businesses via the internet. Consumers can find many alternatives online in a short time. The abundance of alternatives makes it difficult for e-commerce businesses to reach loyal customers. The tendency of potential customers to get the products and services they need from a specific e-commerce website they always prefer without turning to a different e-commerce website is called customer e-loyalty. Continuous and high amounts of expenses of the same customers in processes that have provided eloyalty facilitate meeting operating costs. In this study, it was aimed to investigate the factors affecting the loyalty of customers towards e-commerce marketplaces (trendyol, Hepsiburada, n11, gittigidiyor, amazon, akakçe, etc.). Questionnaire method was used as a data collection tool in the study. In this study conducted with 400 people, it was found that e-trust and e-satisfaction have significant and positive effects on e-loyalty. In addition, other factors affecting e-trust, e-satisfaction and indirectly e-loyalty have been revealed. As a result of the findings, e-commerce marketplaces are expected to create new strategies by taking these factors into account in order to create customer e-loyalty.
\end{abstract}

Keywords: e-commerce, e-commerce marketplace, e-trust, e-satisfaction, e-loyalty

\footnotetext{
* Arş. Gör. Dr., Aydın Adnan Menderes Üniversitesi, Söke İşletme Fakültesi, Yönetim Bilişim Sistemleri Bölümü, busra.kutlu@adu.edu.tr
} 


\section{Giriş}

İşletmeden tüketiciye elektronik ticaret (e-ticaret), tüketicilerin internet aracilı̆̆ıyla işletmelerden doğrudan mal veya hizmet alışverişi yapabilmeleri anlamına gelmektedir. Günümüzde potansiyel tüketiciler zaman kaybettiren ve yüksek fiyatlı ürünlerin pazarlandığı fiziksel ortamlarda gerçekleşen geleneksel alışverişin yerine e-ticaret alışverişini tercih etmektedirler. Ev konforunda kaliteli ürünlere hızla ulaşılmasını sağlayan e-ticaret kullanımı tüketiciler arasında yıldan yıla artmaktadır (T.C. Ticaret Bakanlığı, 2020a). Porter (2001), yakın gelecekte gerçekleştirilecek olan tüm ticaret faaliyetlerinin elektronik hale gelebileceğini öngörmüş ve "e-ticaret" kavramının kullanımının dahi gereksiz hale geleceğini ileri sürmüştür.

Müşterilerin bağlllığı ve tekrar eden satın alımlar olmadan e-ticaret işletmelerinin maliyetlerini karşılayabilmeleri oldukça zordur (Wallace, Giese, \& Johnson, 2004). E-ticaret işletmelerine yönelik müşterilerin e-sadakati müşterilerin aynı e-ticaret işletmelerinin web sitelerini devamlı ziyaret etmelerine ve tekrar tekrar harcama yapmalarına neden olmaktadır (Cyr, Head, \& Larios, 2010). E-ticarete yönelik e-sadakat, e-ticaret işletmelerine yönelik oluşan içten bağılık olarak tanımlanabilmektedir. Gerçek anlamda sadık olan tüketicilerin ilgileri biraz daha çekici bir alternatife doğru kolayca yönlendirilememektedir (Shankar, Smith, \& Rangaswamy, 2003).

E-ticaretin önemli bileşenlerinden olan e-ticaret pazaryerleri (marketplace) ise, çok sayıda satıcıyı içeren çevrim içi mağazalardır. E-ticaret pazaryerlerinde satıcıların müşteri, alıcıların da aradıkları ürünleri bulabilmeleri için bir alan oluşturulmuştur. Çeşitli sektörlerde faaliyet gösteren bir çok satıcı bu platformlarda yer almaktadır. Alıcılar da farklı nitelikte çok sayıda ürüne aynı platform üzerinden erişebilmektedir. Bu sayede tüketiciler aradıkları ürünleri alternatifleriyle karşılaştırarak uygun fiyata ve hızla satın alabilmekte, satıcılar da çok sayıda müşteriye ulaşabilmektedirler (T.C. Ticaret Bakanlığı, 2020b). Trendyol, hepsiburada, n11, gittigidiyor, amazon, akakçe vb. gibi oluşumlar e-ticaret pazaryerlerine örnek gösterilebilmektedir.

$\mathrm{Bu}$ çalışmada e-ticaret pazaryerlerine yönelik e-sadakate etki eden direkt ve dolaylı etkilerin Türkiye örneklemi üzerinde araştırılması amaçlanmaktadır. Bu çalışma Türkiye'de eticaret pazaryerlerine yönelik sadakati inceleyen ilk çalışma olma niteliğindedir.

Bu çalışmanın giriş bölümünde e-ticaret, e-ticaret pazaryerleri ve e-sadakat kavramları hakkında giriş yapılmıştır. İkinci bölümde çalışmanın kavramsal çerçevesi ve araştırmanın hipotezleri ortaya konulmuştur. Araştırmanın yöntemi üçüncü bölümde ortaya konulmuştur. Dördüncü bölümdeki bulgular başlığı altında; doğrulayıcı faktör analizi, Ave, CR, güvenilirlik analizi, korelasyon analizi ve yapısal eşitlik modeli analizi sonuçları incelenmiş̧ir. Son olarak, 
araştırma ölçüm modelinin ölçüm denklik testleri yapılmış ve ölçüm denkliği bulunduktan sonra çoklu grup analizi ile araştırma modelinin kadın ve erkek gruplarda nasıl farklılaştığı araştırılmıştır. Çalışmanın son bölümü olan sonuç ve tartışma bölümünde ise araştırmanın sonuçları yorumlanmış ve ilerideki araştırmalar için önerilerde bulunulmuştur.

\section{Kavramsal Çerçeve}

Ticarette ürün veya hizmetlerin kalitesi çoğunlukla müşteri memnuniyetine, müşterilerin elde tutulabilmesine ve müşteri sadakatine yol açmaktadır. Bu durumun elektronik perakendecilikte de benzer şekilde gerçekleşmesi beklenmektedir. Bu bağlamda elektronik perakendeciliğin başarısının bir kıstası olarak adledilen elektronik perakendeciliğin kalitesinin tanımlanması gerekmektedir. Wolfinbarger ve Gilly (2003), “çevrimiçi sipariş edilen ürün veya hizmete yönelik bilgi arama, websitesinde gezinme, sipariş verme, müşteri hizmetleri ile olan etkileşim, teslimat ve memnuniyeti kapsayan elektronik perakendeciliğin kalitesi kavramını tanımlamak ve ölçmek için” eTailQ ölçeği geliştirmiştir. Bu ölçek yalnızca web sitesindeki ürün ile ilgili durumları değil, ürünün beklenildiği gibi ve zamanında gelmesi gibi çevrimdışı süreçleri de içermektedir. ETailQ ölçeğinin icra etme/gerçekleştirme, web sitesi tasarımı, müşteri hizmetleri ve güvenlik/gizlilik olmak üzere dört adet boyutu bulunmaktadır.

$\mathrm{Bu}$ araştırmada e-ticaret pazaryerlerine (trendyol, hepsiburada, n11, gittigidiyor, amazon, akakçe vb.) yönelik e-sadakat kavramının incelenmesi amaçlanmaktadır. E-sadakat; pek çok alternatif mevcutken, müşterilerin çoğunlukla aynı e-ticaret pazaryerlerini ziyaret ederek alışveriş yapmaları anlamına gelmektedir (Cyr, 2008). Bu alanda gerçekleştirilen pek çok çalışma e-güven ve e-memnuniyetin ayrı veya birlikte e-sadakat üzerinde etkilerinin olduğunu ortaya koymaktadır (Reichheld \& Reprint, 2000; Sirdeshmukh, Singh, \& Sabol, 2002; Anderson \& Srinivasan, 2003; Gummerus, Liljander, Pura, \& Van Riel, 2004; Safa \& Ismail, 2013; Husain, 2017).

E-sadakat kavramı incelenirken e-güven ve e-memnuniyet kavramlarının incelenmesi gerekmektedir. Bu çalışmada EtailQ ölçeğinin, e-WOM'un (electronic Word of Mouthelektronik ağızdan ağıza haberleşme) ve web sitesinin ünü/tanınırlığının e-güven ve ememnuniyete olan direkt etkileri araştırılacaktır. e-WOM kavramı, müşterilerin e-perakende websitesinde yer alan ürünlere yönelik pozitif yorumlarını ve değerlendirmelerini işaret ederken (Yoo, Sanders, \& Moon, 2013), web sitesinin tanınırlığı kavramı web sitesinin toplumda ünlü ve bilinir olması anlamına gelmektedir (Torres-Moraga, Vásquez-Parraga, \& Barra, 2010). 


\subsection{Hipotezlerin Kavramsal Yapısı}

Ağızdan ağıza haberleşme (Word of Mouth-WOM) kitlelerin ürün/hizmetler hakkındaki deneyimlerini, düşüncelerini ve gözlemlerini birbirlerine aktarmaları ve söz konusu ürün/hizmetlerden geniş kitlelerin haberdar olmasını sağlamaları anlamına gelmektedir. İnternet vasıtasıyla gerçekleşen ağızdan ağıza haberleşme ise "e-WOM" olarak ifade edilmektedir. e-WOM; “mevcut, önceki veya potansiyel müşterilerin bir ürün, hizmet veya organizasyon hakkında internet aracılığı ile sundukları ve milyonlarca kişiye açık olan pozitif ya da negatif bildirimlerdir" (Hennig-Thurau \& Walsh, 2003). E-WOM internet alışverişlerinde önemli bir bilgi kaynağı olarak yerini korumaktadır. Geleneksel WOM faaliyetleri zamanla ve belirli ilişkilerle sınırlıdır ve e-WOM kadar büyük bir etki oluşturamamaktadır (Yoo vd., 2013, S. 669).

e-WOM faaliyetleri gerçekleştiren her e-ticaret işletmesi müşterilerin gözünde olumlu imaja, üne ve itibara sahip olmayı dilemektedirler. Bu sonucu elde edebilmek için e-ticaret işletmeleri tarafından müşterilere önceden iyi deneyimler sunulmuş olması gerekmektedir. Bir diğer ifadeyle, müşteriler bir e-ticaret web sitesinde gerçekleştirdikleri herhangi bir sipariş sürecini tatmin edici bir şekilde tamamlamlandıklarına dair değerlendirmelerde bulunduklarında söz konusu e-ticaret işletmesinin ünü artış göstermektedir (Vos vd., 2014, s. 422). Bu çalışmada ise yalnızca olumlu değerlendirmelerin değil e-ticaret web sitesinde yer alan olumlu/olumsuz tüm değerlendirmelerin şeffaf bir şekilde diğer müşterilerle paylaşılmasının e-ticaret web sitesinin ününü/bilinirliğini arttıracağı ileri sürülmektedir. Buna göre aşağıdaki hipotez oluşturulmuştur:

Hla: Elektronik ăğzdan ăğza iletişim (e-WOM), e-ticaret pazaryerlerinin bilinirliğini anlamlı ve pozitif olarak etkilemektedir.

Fikir beyan etmek, geri bildirim, yorum ve önerilerde bulunmak e-WOM sürecinin en belirgin özelliklerindendir (Yoo vd., 2013). Güven ise müşterilerin işletmenin, hizmetlerin veya ürünlerin kalitesine ve güvenilirliğine yönelik oluşan inançlarıdır (Garbarino \& Johnson, 1999). Güven e-ticarette alışverişin başlaması, düzenlenmesi ve sürdürülmesi konularında büyük önem taşımaktadır (Verhoef, Franses, \& Hoekstra, 2002). Güven duygusunun sağlandığı eticaret işletmelerinde daha fazla alım-satım işlemi gerçekleştirilmektedir.

Alanyazında e-WOM'un güven üzerinde etkili olduğu olduğuna dair pek çok çalışma yer almaktadır. Sosyal ağlarda satın alma niyeti (See-to \& Ho, 2014), çevrimiçi satın alma niyeti (Awad \& Ragowsky, 2008), e-ticarette satın alma niyeti (Chan \& Ngai, 2011) ve müşteriden müşteriye e-ticarette satın alma niyeti (Fu, Zhang, Xie, Xiao, \& Che, 2011) çalışmalarında eWOM'un ürüne güveni, çevrimiçi güveni ve müşteri güvenini anlamlı ve pozitif etkilediği 
bulunmuştur. Yukarıdaki çalışmalarla paralel olarak elektronik ağızdan ağıza iletişimin sağlandığı e-ticaret pazaryerlerinde tüm müşteriler ürün ve hizmetler hakkında gerçek değerlendirmelere ulaşılabileceğinden söz konusu e-ticaret pazaryerlerine yönelik güven duygusunun oluşacağı tahmin edilmektedir. Bu bilgilerin ışığında aşağıdaki araştırma hipotezi ileri sürülmüştür:

HIb: Elektronik ă̆ızdan ă̆ıza iletişim (e-WOM), e-güveni anlamlı ve pozitif olarak etkilemektedir.

İcra etme/gerçekleştirme kavramı bir e-ticaret web sitesinde tam olarak özellikleri gösterilmiş olan bir ürünün söz verilen zamanda teslim edilmesi ve müşterilerin tam olarak bekledikleri ürünü elde etmeleridir (Wolfinbarger \& Gilly, 2003). Bir diğer ifadeyle vaadedilen hizmetlerin doğru, güvenilir, hızlı ve zamanında gerçekleştirilmesi olarak nitelendirilebilmektedir (Rodríguez, Villarreal, Valiño, \& Blozis, 2020).

E-ticaret sürecinde e-perakendecinin yanlış ürün teslimatı veya doğru ürünleri zamanında teslim etmede tamamen ya da kısmen başarısız olması halinde, tüketicinin eperakendeciye karşı olan güven duygusu hasar almaktadır (Butt vd., 2018). Geçmişte yapılan birçok çalışmada, siparişin doğru şekilde yerine getirilmesiyle tüketicinin çevrimiçi perakendeciye olan güveni arasında pozitif bir ilişki bulunduğu sonucuna ulaşılmıştır. Eperakendicilere yönelik sadakati (Al-Dweeri, Moreno, Montes, Obeidat, \& Al-Dwairi, 2018), e-ticarette e-sadakati (Kim vd., 2009; Giovanis \& Athanasopoulou, 2014), yükseköğretim kurumlarının web sitelerine (websitesi, portal, sosyal medya sitelerine) yönelik e-sadakati (Leonnard, 2019) ve çevrimiçi satın alma niyetini (Chek \& Ho, 2016) araştıran çalışmalarda icra etme/gerçekleştirmenin e-güven üzerinde anlamlı ve pozitif bir etkiye sahip olduğu belirtilmektedir. Alanyazında yer alan bu bilgilerin 1şı̆̆ında e-ticaret pazaryerlerinin vaadettiklerini gerçekleştirmesi anlamında kullanılan icra etme/gerçekleştirmenii, e-ticaret pazaryerlerine yönelik e-güveni pozitif olarak etkileyeceği düşünülmektedir. Buna göre aşağıdaki araştırma hipotezi ileri sürülmüştür:

H2a: Ícra etme/gerçekleştirme, e-güveni anlamlı ve pozitif olarak etkilemektedir.

İcra etme/gerçekleştirme çevrim içi satıcıların taahüt ettikleri ürünü/hizmeti taahüt ettikleri koşullarda teslim etmeleri anlamına gelmektedir (Cristobal, Flavián, \& Guinalíu, 2007). Bu süreç ürün veya hizmetlerin sipariş edilmesi ve teslim edilmesi arasındaki zaman diliminde gerçekleşmektedir (Wolfinbarger \& Gilly, 2003). Doğru ürünler, taahüt edilen zamanda ve tam olarak tarif edildiği gibi müşterilere ulaştığında müşteriler eticarvdışverişlerine yönelik memnuniyet duygusu yaşamaktadırlar. 
Alanyazında e-ticarette icra etme/gerçekleştirmenin müşteri tatminine yol açtığ sonucuna ulaşan çok sayıda çalışma bulunmaktadır. İnternet bankacılığı sadakati (Quan, 2010), çevrimiçi alışverişte satın alma niyeti (Lee \& Lin, 2005), e-perakendecinin kalitesi (Wolfinbarger \& Gilly, 2003), e-perakendecilikte memnuniyet (Collier \& Bienstock, 2006) ve e-perakendeciye yönelik e-sadakat (Kim vd., 2009; Semeijn vd., 2005) çalışmalarında icra etme/gerçekleştirmenin müşteri tatminini anlamlı ve pozitif olarak etkilediği sonucuna ulaşılmaktadır. Alanyazındaki bu çalışmaların ışığında icra etme/gerçekleştirmenin e-ticaret pazaryerlerine yönelik memnuniyeti anlamlı ve pozitif olarak etkileyeceği varsayılmaktadır. Buna göre aşağıdaki araştırma hipotezi ortaya konulmuştur:

H2b: Ícra etme/gerçekleştirme, e-memnuniyeti anlamll ve pozitif olarak etkilemektedir.

Güvenlik/gizlilik; kredi kartı bilgilerinin ve ödemelerinin güvenliği (Wolfinbarger \& Gilly, 2003) ve müşterilerin tüm çevrimiçi işlemlerinin güvenliği (Rodríguez vd., 2020). olarak nitelendirilebilmektedir. Miyazaki \& Fernandez (2001)'e göre çevrimiçi satıcılar müşterilerin güvenini kazanmak için gizlilik şartlarını sağladıklarını ve güvenlik sızıntılarını engellediklerini açıkça gösterilmelidir.

Çevrimiçi perakendecilik işlemlerinin artması için güvenlik/gizlilik konusunda tüketiciler satıcıların işbirliğine, güçlü isteğine ve yeteneklerine güven duymalıdır (Pavlou, Liang, \& Xue, 2007). Tüketiciler çevrimiçi perakendecilerin şahsi bilgilerini topladıklarını ve kötüye kullanacaklarını düşündüklerinde çevrimiçi perakendicelere karşı güven duyguları büyük ölçüde azalmaktadır (Eastlick, Lotz, \& Warrington, 2006).

Alanyazındaki pek çok çalışmada güvenlik/gizliliğin müşteri güveni oluşturma konusunda büyük önem arzettiği sonucuna ulaşılmaktadır (Urban, Sultan, \& Qualls, 2000; Ribbink, Van Riel, Liljander, \& Streukens, 2004; Kim vd., 2009; Rodríguez vd., 2020). Bu bilgilerin ışığında bu araştırmada da güvenlik/gizlilik arttıkça, e-ticaret pazaryerlerine yönelik güvenin artacağı varsayılmaktadır. Buna göre aşağıdaki araştırma hipotezi ileri sürülmüştür:

H3a: Güvenlik/gizlilik, e-güveni anlaml ve pozitif olarak etkilemektedir.

Çevrimiçi alışverişte müşteriler firmayla fiziksel etkileşime giremediğinden e-ticaret websitesine yönelik çevrimiçi güven farklı yöntemlerle kurulmaya çalışılmaktadır. Çevrimiçi alışverişte müşteri güveni sağlamanın yollarından biri müşteriler için güvenli ödeme olanaklarının oluşturulabilmesidir. Bir e-ticaret web sitesinde güvenlik/gizliliğin sağladığının en belirgin kanıtı ise; e-ticaret sitesinden hizmvdan müşterilerin kişisel bilgilerinin nasıl yönetildiğini açıklayan gizlilik politikalarıdır (Al-Dweeri vd., 2018, s. 907). Bu gizlilik politikaları müşterilerden toplanan bilgilerin satılmayacağına ve değiştirilmeyeceğine dair 
taahütleri içermelidir (Parasuraman, Zeithaml, \& Malhotra, 2005). Taahütlerin verilmesi kadar verilen sözlerin e-ticaret web siteleri tarafından özenle yerine getirilmesi de önemlidir.

E-ticaret sitelerinin güvenlik/gizlilik özelliklerine özen göstermesi müşteri memnuniyeti üzerinde önemli bir etkiye sahiptir. Alanyazındaki pek çok çalışma bu ifadeyi desteklenmektedir. Sosyal ağları kullanmaya devam etme niyeti (Tran, Pham, \& Le, 2019), eticaret sitelerinin e-hizmet kalitesi (Kim \& Kim, 2010) ve Türkiye ve Rusya'da çevrimiçi gizlilik ve e-sadakat ilişkisinin karşılaştırılması (Malakmadze, Ünver, \& Arıkan, 2017) çalışmalarında güvenlik/gizliliğin memnuniyeti anlamlı ve pozitif etkilediği bulunmuştır. $\mathrm{Bu}$ çalışmalar ile paralel olarak e-ticaret pazaryerlerinin güvenlik/gizlilik özelliklerinin müşterilerin memnuniyetini pozitif etkileyeceği tahmin edilmektedir. Buna göre aşağıdaki araştırma hipotezi oluşturulmuştur:

H3b: Güvenlik/gizlilik, e-memnuniyeti anlamll ve pozitif olarak etkilemektedir.

Çevrimiçi alışveriş literatüründe müşteri hizmetleri; çevrim içi hizmetlerin kalitesi ve kusursuzluğu hakkındaki müşteri değerlendirmeleri ve yargılarını içermektedir (Santos, 2003). Aynı zamanda çevrimiçi perakendecilerin müşterilerin sorgulamalarına yönelik hızlı cevapları, yardımcı olma istekleri ve tüm müşterilerle ilgilenebilecek zaman yaratabilmeleri şeklinde de nitelendirilebilmektedir (Kim \& Lee, 2002).

Müşteriler çevrimiçi alışverişlerinde mümkün olan en iyi müşteri hizmetleri ile karşılaşmayı dilemektedirler. Müşteri hizmetleri özellikle ürün/hizmet teslim süreci, kalitesi ve teslimat/fatura koşulları ve satın alım sonrası destek ihtiyacı gibi özel durumlar yaşandığında önemli hale gelmektedir. Bu durumlarda müşterilerin müşteri hizmetlerine hızla ulaşabilmeleri ve sorunlarına yönelik anlamlı bir çözüm elde edebilmeleri çevrimiçi satıcıya yönelik güven duygusunun oluşmasına zemin hazırlamaktadır. Konradt, Wandke, Balazs, \& Christophersen (2003) çevrimiçi alışverişte satın alma niyetini araştırdıkları çalışmalarında müşteri hizmetleri ve güveninin pozitif ilişkili olduğu ve Kim vd. (2009) e-perakendecilere yönelik e-sadakati araştırdıkları araştırmalarında, müşteri hizmetlerinin e-perakendecilere yönelik oluşan e-güveni arttığı sonucuna ulaşmışlardır. Ancak diğer taraftan, Yıldız ve Karadirek (2014) internet bankacılığında e-hizmet kalitesini araştırdıkları çalışmalarında müşteri hizmetlerinin e-güven üzerinde etkisinin olmadığı sonucunu elde etmişlerdir. Alanyazındaki söz konusu karmaşık bulguların neticesinde müşteri hizmetlerinin e-ticaret pazaryerlerine yönelik olan e-güveni anlamlı ve pozitif etkileyeceği düşünülmektedir. Buna göre aşağıdaki araştırma hipotezi ileri sürülmüştür:

H4a: Müşteri hizmetleri, e-güveni anlamlı ve pozitif olarak etkilemektedir. 
Müşteri hizmetleri çevrimiçi alışveriş sürecinde tüketicilerin karşılaştıkları sorunlara yönelik çözüm geliştirilebilme yeteneğidir. Müşteri memnuniyeti ise satın alma deneyiminin değerlendirilmesini içerdiğinden çoğunlukla tüketim tecrübesinden sonra oluşmaktadır (Gounaris, Dimitriadis, \& Stathakopoulos, 2010). Uzun dönemli müşteri ilişkileri oluşturulabilmesi ve sürdürebilmesi için çevrimiçi alışverişlerin sonucunda memnuniyet sağlayan deneyimlerin sunulmuş olması gerekmektedir (Omar, 2009).

Sorgularına hızla, hevesle ve samimiyetle yaklaşılan müşterilerde memnuniyet hissi oluşabilmektedir. Alanyazında müşteri desteğinin memnuniyet üzerinde etkisinin olduğunu belirten çok sayıda çalışma bulunmaktadır. E-ticaret memnuniyeti ve tercihi (Devaraj, Fan, \& Kohli, 2002), çevrimiçi alışverişte e-hizmetlerin kalitesi (Lee \& Lin, 2005) ve e-perakendecinin marka değeri (Butt vd., 2018) çalışmalarında müşteri hizmetlerinin e-memnuniyeti anlamlı ve pozitif olarak etkilediği sonuçlarına ulaşılmıştır. Diğer taraftan e-perakendeciye yönelik olan esadakat (Kim vd., 2009) ve e-ticarette e-sadakakat (Kassim \& Abdullah, 2010) çalışmalarında müşteri hizmetlerinin memnuniyet üzerinde etkisinin olmadığ 1 bulunmuştur. Alanyazındaki karmaşık sonuçların neticesinde müşteri hizmetlerinin e-memnuniyet üzerindeki etkisinin belirlenmesi oldukça mühim bir konudur. $\mathrm{Bu}$ çalışmada müşteri hizmetlerinin e-ticaret pazaryerlerine yönelik e-memnuniyet üzerinde anlamlı ve pozitif bir etkisinin olacağı varsayılmıştır. Buna göre aşağıdaki araştırma hipotezi oluşturulmuştur:

H4b: Müşteri hizmetleri, e-memnuniyeti anlaml ve pozitif olarak etkilemektedir.

Geleneksel mağaza tasarımında olduğu gibi, web site tasarımı da çevrimiçi perakendeciye ait işletmeyi temsil etmektedir. Çevrimiçi perakendicilerin müşterilerde iyi bir izlenim oluşturabilmeleri için güncel, hızlı, bilgilendirici, düzenli ve gezinmesi kolay bir web sitelerine sahip olmaları gerekmektedir (Kim vd., 2009). İyi tasarlanmış web siteleri gerçekleştirilen işlemleri kolaylaştırmakta ve tüketicilere zaman kazandırmaktadırlar. Bu durum tüketicilerde belirli avantajlara yol açtığı için genel olarak memnuniyete yol açmaktadır.

Alanyazında web tasarımının memnuniyete yol açtığı bulgusunu destekleyen çok sayıda çalışma bulunmaktadır. E-perakendeciliğe yönelik e-memnuniyet (Szymanski \& Hise, 2000), web site tasarımının güven, memnuniyet ve sadakat üzerindeki etkisi (Cyr, 2008), eperakendeciye yönelik e-sadakat (Kim vd., 2009) ve çevrimiçi alışverişte müşteri memnuniyeti (Alam \& Yasin, 2010) çalışmalarında web tasarımının memnuniyeti anlamlı ve pozitif etkilediği sonucuna ulaşılmıştır. Bu bilgilere paralel olarak bu çalışmada e-perakendecilerin web sitesinin iyi tasarım özelliklerine sahip olmasının e-ticaret pazaryerlerine yönelik ememnuniyeti arttıracağı ileri sürülmektedir. Buna göre aşağıdaki hipotez oluşturulmuştur:

H5:Web tasarımı, e-memnuniyeti anlamlı ve pozitif olarak etkilemektedir. 
Çoğunlukla belirsizliklerin ve risklerin yer aldığı çevrimiçi ortamlarda müşterilere ulaşmak ve onların güvenini kazanmak oldukça zor bir görevdir (López-Miguens \& Vázquez, 2017). İyi bilinen, hatırlanan, aşina olunan işletmeler hiç bilinmeyen veya az bilinen işletmelere göre daha fazla güven vermektedir. Ün/tanınırlık özellikleri müşterilerle ilişkilerin başlamasına ve sürdürülmesine büyük bir katkı sağlamaktadır. McCole (2002)'a göre çevrimiçi müşteriler daha önce herhangi bir etkileşimde bulunmadıkları e-ticaret işletmeleriyle karşı karşıya kaldıklarında alışveriş için tercihlerini daha çok bilinen işletmelerden yana kullanmaktadırlar. $\mathrm{Bu}$ durumda çoğu e-ticaret işletmesi müşterilerin güvenini elde edebilmek için ün/tanınırlık özelliklerini arttırmaya çalışmaktadır.

Alanyazında ün/tanınırlığın güveni arttırdığı ifadesini destekleyen çok sayıda çalışma bulunmaktadır. İnternet işletmelerinde güven oluşturma (Mcknight, Kacmar, \& Choudhury, 2004), e-ticarette müşteri güveni (Teo \& Liu, 2007), çevrimiçi perakendecilikte e-güven (Wang, Wang, Wu, \& Zhang, 2012) ve e-ticarette güven ve bağlllık (Sivakumaran, Auburn, \& Maheswarappa, 2014) çalışmalarında bilinirliğin güveni anlamlı ve pozitif etkilediği sonuçlarına ulaşılmıştır. $\mathrm{Bu}$ bulguların ışığında e-ticaret pazaryerlerinin ününün e-ticaret pazaryerlerine güveni temsil eden e-güveni pozitif etkileyeceği düşünülmektedir. Buna göre aşağıdaki araştırma hipotezi oluşturulmuştur:

H6: E-ticaret pazaryerlerinin ün/tanınırlı̆̆l, e-güveni anlamlı ve pozitif olarak etkilemektedir.

Çevrimiçi perakendecilik; teslimat, ödeme ve bilgi paylaşımı gibi konularda yüksek seviyede risk içermektedir. Bu sebeplerden ötürü çevrimiçi müşteriler çoğunlukla güvendikleri e-perakendecilerden alışveriş yapmayı tercih etmektedirler (Singh \& Sirdeshmukh, 2000). Güven duyulan işletmelerden gerçekleştirilen güvenli alışverişler müşterilerde haz ve memnuniyet duygusu oluşturmaktadır. Memnuniyet sahibi müşterilerin ise aynı işletmeyi tekrar tekrar tercih edeceği düşülünmektedir

Alanyazındaki pekçok çalışmada çevrimiçi ortamlarda güvenin memnuniyetin tahminleyicisi olduğu bulunmuştur. Çevrimiçi sağlık hizmetleri web sitelerinde e-sadakat (Gummerus vd., 2004), çevrimiçi alışveriş sitelerinde sadakat (Jin \& Park, 2006), e-ticaret etiği ve müşteri sadakati (Kurt, 2013), çevrimiçi perakende alışveriş sitelerine yönelik sadakat (Yaşin, Özkan, \& Baloğlu, 2017) çalışmalarında bu ifade desteklenmektedir. Bulunan sonuçların ışığında bu araştırmada tüketicilerin bir e-ticaret pazaryerlerine güven duymalarının tüketicilerin e-ticaret pazaryerlerine yönelik memnuniyetlerini arttıracağı tahmin edilmektedir. Buna göre aşağıdaki araştırma hipotezi oluşturulmuştur:

H7a: E-güven, e-memnuniyeti anlamll ve pozitif olarak etkilemektedir. 
E-güven, çevrimiçi alışverişlerde müşterilerin çevrimiçi perakendecinin ürün bilgilendirmelerine, vaatlerine ve çevrimiçi perakendicinin kendisine yönelik olan inançları olarak nitelendirilmektedir. Müşteriler alışveriş esnasında güven duydukları çevrimiçi perakendecilerle kişisel bilgilerini, alışveriş alışkanlıklarını, alışveriş sürelerini, zevk ve beğenilerini paylaşmakta ve sunulan pek çok hizmetin kişiselleştirilebilmesini mümkün kılmaktadırlar. Çok sayıda müşteri bilgisine sahip olan e-ticaret işletmeleri bu sayede her bir müşteriye en uygun ürün ve hizmetleri sunabilmektedirler. Güven duydukları ve kendilerini iyi tanıyan e-ticaret işletmelerinden alışveriş yapan çevrimiçi müşteriler ise aynı tecrübeyi yeniden deneyimlemek isteyeceklerdir. Müşterilerin pek çok alternatif olduğu halde aynı çevrimiçi perakendecilerin web sitelerini ziyaret etmeleri, ihtiyaç anında öncelikli olarak aynı perakendecinin ürünlerini incelemek istemeleri ve tercih ettikleri perakendecilere karşı pozitif tutum beslemeleri e-sadakat olarak anılmaktadır (Toufaily, Ricard, \& Perrien, 2013). Sonuç olarak güvenilir e-ticaret işletmelerinin tekrarlayan satın alımlar ve sadık müşteriler yaratacağı sonucuna rahatlıkla ulaşılabilmektedir.

Alanyazında çevrimiçi ortamda güvenin memnuniyet yol açtığı sonucuna ulaşan pek çok araştırma yer almaktadır. Çevrimiçi e-sadakat (Reichheld \& Reprint, 2000), çevrimiçi müşteri sadakati (Pitta, Franzak, \& Fowler, 2006), ticari web sitelerinde müşteri sadakati (Toufaily vd., 2013), e-ticatte müşteri sadakati (Safa \& Ismail, 2013), çevrimiçi perakende alışveriş sitelerine yönelik sadakat (Yaşin vd., 2017), çevrimiçi alışveriş platformlarında esadakat (Zheng, Lee, \& Cheung, 2017), çevrimiçi e-müşteri sadakati (Sevim, 2018) ve çevrimiçi yeniden satın alma niyeti (Bulut \& Karabulut, 2018) çalışmalarında güvenin sadakati anlamlı ve pozitif olarak etkilediği bulunmuştur. Alanyazındaki çalışmalarla paralel olarak bu çalışmada e-ticaret pazaryerlerine yönelik olan e-güvenin, e-perakendeciye yönelik olan esadakati anlamlı ve pozitif etkileyeceği varsayılmaktadır. Buna göre aşağıdaki araştırma hipotezi oluşturulmuştur:

H7b: E-güven, e-sadakati anlaml ve pozitif olarak etkilemektedir.

Çevrimiçi perakendecilikte müşteri e-memnuniyeti, müşterilerin önceki tecrübelerini dikkate alarak e-perakendecilik hizmetini değerlendirmeleri sonucunda oluşmaktadır (Rodríguez vd., 2020). Tüketiciler memnuniyet yaratan e-perakendecilerle ilişkilerini sürdürmek istemektedirler (Fang, Shao, \& Wen, 2016). Müşteriler ve belirli perakendeciler arasındaki ilişkilerin düzenli olarak devam ettirilmesi sadık müşteri karakterlerinin oluşmasına yol açmaktadır. Sadık müşteriler ise çoğunlukla aynı perakedenciden yeniden satın alma davranışı göstermektedirler. 
Memnuniyet ve e-sadakat (Anderson \& Srinivasan, 2003), çevrimiçi tüketici davranışları (Cai \& Xu, 2006), e-perakendeciye yönelik e-sadakat (Kim vd., 2009), e-ticatte müşteri sadakati (Safa \& Ismail, 2013), Türkiye ve Rusya'da çevrimiçi gizlilik ve e-sadakat ilişkisinin karşılaştırılması (Malakmadze vd., 2017), e-ticarette müşteri sadakati (Gong-min, 2010), çevrimiçi e-müşteri sadakati (Sevim, 2018) ve e-sadakatte e-memnuniyetin aracı rolü (Sai Vijay, Prashar, \& Sahay, 2019) çalışmalarında e-memnuniyetin e-sadakati anlamlı ve pozitif etkilediği sonucuna ulaşılmaktadır. Bu çalışmalar ile paralel olarak aşağıdaki araştırma hipotezi ortaya konulmuştur:

H8: E-memnuniyet, e-sadakati anlamlı ve pozitif olarak etkilemektedir.

\section{Yöntem}

Bu bölümde, araştırmanın amacı ve katkısı, araştırma modeli ve ölçekleri, veri toplama ve analiz yöntemi ve en son olarak araştırmanın ana kütlesi ve örneklemi sunulmuştur.

\subsection{Araştırmanın Amacı ve Katkısı}

Potansiyel müşterinin farklı bir e-ticaret web sitesine yönelmeden, ihtiyaç duyduğu ürün ve hizmetleri her zaman tercih ettiği belirli bir web sitesinden alma isteği ve eğilimine müssteri e-sadakati denilmektedir. Bir diğer ifadeyle müşteri e-sadakati müşterilerin belirli bir e-ticaret web sitesindeki tekrar eden satın alma davranışlarıdır (Al-Adwan \& Al-Horani, 2019).

Çevrimiçi ortamda müşteriler çok fazla emek ve zaman harcamadan, bir tık ile farklı eticaret sitelerine ulaşabilmektedir. Alternatiflerin fazlalılığı sebebiyle geleneksel işletmelerin aksine e-ticaret işletmelerinde müşteriyi ilk alışveriş için çekebilmek oldukça zordur. Ancak bu işletmeler doğru stratejiler uyguladıkları takdirde müşterilerin sitedeki devamlılıklarını sağlamak geleneksel işletmelere göre daha az maliyetli ve daha kolaydır. Müşteri e-sadakatini sağlamış olan işletmeler ürün yelpazelerini geliştirdikçe sadık müşteriler gereksinim duydukları ürünleri aynı e-ticaret web sitesinden satın alma eğilimde olmaktadır (Reichheld \& Reprint, 2000).

$\mathrm{Bu}$ çalışmanın amacı müşterilerin e-ticaret pazaryerlerinine yönelik müşteri sadakatine etki eden faktörleri araştırmaktır. Bu çalışmanın e-ticaretpazaryerlerinin müşteri e-sadakati yaratmak için yeni iş stratejileri tasarlamalarına yardımcı olması ve özellikle e-ticaret pazaryerleri alanındaki yeni araştırmalara yön vermesi beklenmektedir.

\subsection{Araştırmanın Modeli ve Ölçekleri}

E-ticaret pazaryerlerine yönelik müşteri sadakatini (e-sadakati) etkileyen; e-ağızdan ağıza iletişim (e-WOM), icra etme/gerçekleştirme, güvenlik/gizlilik, müşteri hizmetleri, web 
tasarımı, ün/tanınırlık, e-güven, e-memnuniyet değişkenlerinin direkt ve dolaylı etkilerinin ve cinsiyetin rolünün araştırıldığı araştırma modeli Şekil 1'de gösterilmektedir.

\section{Şekil 1. Araştırma modeli}

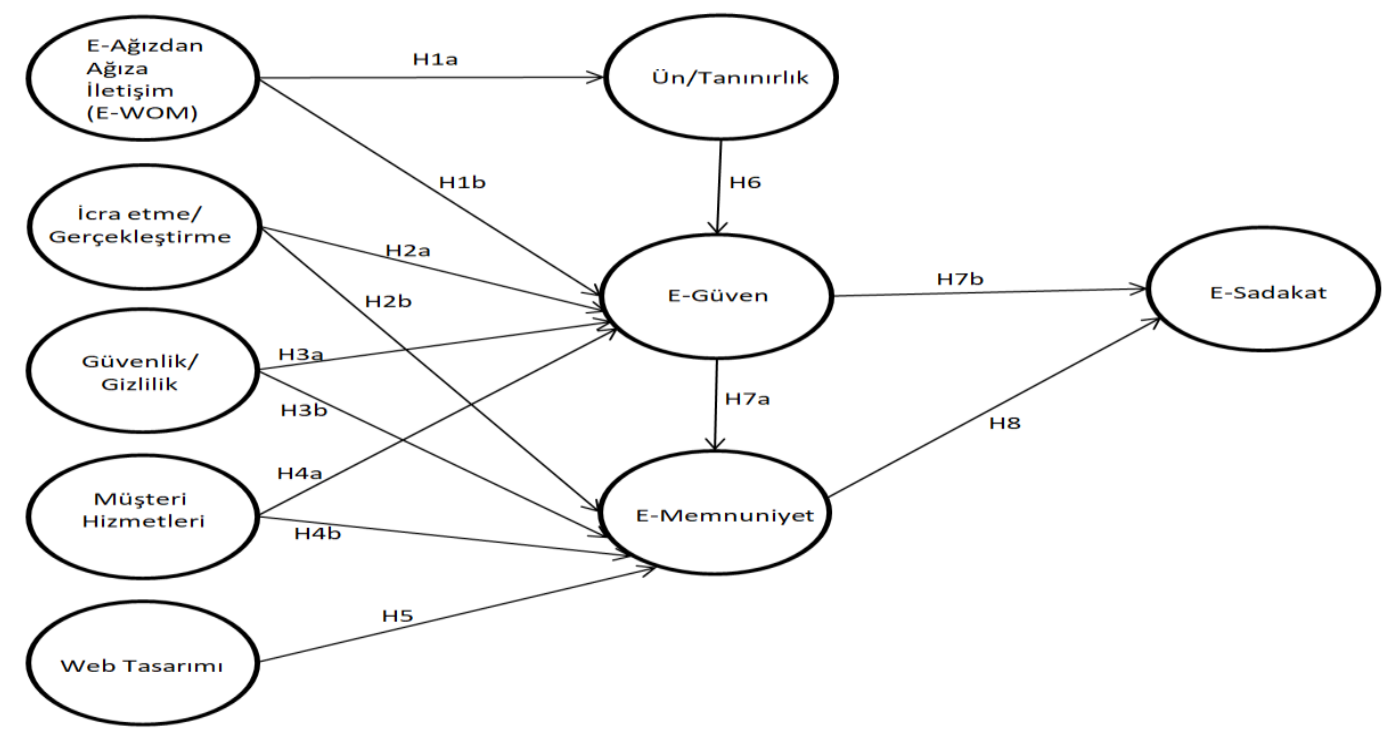

Literatürde daha önceden geliştirilmiş olan ve bu araştırmada ele alınan tüm ölçekler Tablo 1'de gösterilmektedir. Veri toplama aracında toplam 29 madde bulunmaktadır. Yabancı dilde oluşturulan ölçeklerin Türkçe diline çeviri aşamasında 5 aşamalı teknik kullanılmıştır. Bu aşamalar, ilk çeviri, ilk çeviriyi değerlendirme, geri çeviri, geri çeviriyi değerlendirme ve uzman görüşünü içermektedir (Brislin, Lonner, \& Thorndike, 1973). Tüm ölçekler öncelikle 2 İngiliz Dili ve Edebiyatı öğretim üyesi tarafından Türkçe'ye çevrilmiştir. Daha sonra bu ölçekler 3 farklı konunun uzmanı/alan uzmanı tarafından değerlendirilmiştir. Değerlendirmede ölçek maddelerinin okuyucular tarafından anlaşılırlığı ve kültürel uyumluluğu incelenmiştir. Değerlendirme neticesinde elde edilen Türkçe ölçekler, 2 İngiliz Dili ve Edebiyatı öğretim üyesi tarafindan yeniden İngilizce diline çevrilmiştir. Elde edilen İngilizce ölçekler, ölçeklerin orijinal haliyle karşılaştırılmıştır. En son aşamada ise tüm ölçekler 2 farklı uzman görüşüne sunulmuştur. Uzman görüşleri sonrasında ölçeklerin nihai hali ortaya çıkmış ve bu çalışmada kullanılması kararlaştırılmıştır (Çetin \& Basım, 2012).

$\mathrm{Bu}$ çalışmada ele alınan, Al-Adwan ve Al-Horani (2019) tarafından sunulan ölçek maddeleri Wolfinbarger ve Gilly (2003), Kim vd. (2009), Li, Tevrizci, ve Aham-Anyanwu (2014) ve Liu ve Guo (2017) ana kaynaklarından elde edilmiştir. 


\section{Tablo 1. Ölçek maddeleri}

\begin{tabular}{cc} 
Maddeler Ölçek İsmi \\
\hline
\end{tabular}

E-S1:Herhangi bir ürün satın almak istediğimde, bu çevrimiçi alışveriş websitesi ilk tercihimdir.

E-S2:Bu çevrimiçi alışveriş websitesi aynı türdeki ürünleri satın alırken kullanmayı en sevdiğim sitedir.

E-Sadakat

E-S3:Bana göre bu site en iyi çevrimiçi alı̧̧veriş websitesidir.

E-S4:Almakta olduğum hizmet devam ettiği sürece, başka bir web sitesine geçeceğimden şüpheliyim.

E-G1:Bu çevrimiçi alışveriş websitesinin ürün bilgilendirmelerine inanıyorum.

E-G2:Bu çevrimiçi alışveriş websitesi güvenilirdir.

E-G3:Bu çevrimiçi alışveriş websitesinin bir ürün hakkındaki iddialarına ve vaatlerine

E-Güven güveniyorum.

E-M1:Bu çevrimiçi alışveriş websitesinin ürünlerinden memnunum.

E-M2:Genel anlamda, bu çevrimiçi alışveriş websitesinden memnunum.

E-M3:Bu çevrimiçi alışveriş websitesi ile gerçekleştirdiğim satın alma deneyiminden

E-Memnuniyet memnunum.

İC1:Ürünler bu çevrimiçi alışveriş websitesi tarafından doğru tanıtılmaktadır.

IC2:Ürünler bu çevrimiçi alışveriş websitesinin vaat ettiği gibi zamanında teslim edilir.

İC3:Bu çevrimiçi alışveriş websitesinden tam olarak sipariş ettiğim ürünü teslim alırım.

İcra etme/

Gerçekleştirme

MH1:Bu çevrimiçi alışveriş websitesi, müşterilerin ihtiyaçlarını cevaplamaya hazır ve isteklidir.

MH2:Bu çevrimiçi alışveriş websitesinde sorular hızla cevaplanır.

Müşteri

MH3:Bir sorun yaşandığında, bu çevrimiçi alışveriş websitesi sorunu çözmek için samimi bir

Hizmetleri yaklaşım gösterir.

WT1:Bu çevrimiçi alışveriş websitesi, zaman kaybı oluşturmayacak şekilde tasarlanmıştır.

WT2:Bu çevrimiçi alışveriş websitesi detaylı bilgi sunmaktadır.

Website

WT3:Bu çevrimiçi alışveriş websitesinde bir işlemi tamamlamak hızlı ve kolaydır.

Tasarımı

G1:Bu çevrimiçi alışveriş websitesi, yeterli güvenlik vasıflarına sahiptir.

G2:Bu çevrimiçi alışveriş websitesi yaptı̆̆ım işlemlerde kendimi güvende hissediyorum.

Güvenlik/

G3: $\mathrm{Bu}$ çevrimiçi alışveriş websitesinde, gizliliğimin (mahremiyetimin) korunduğunu

Gizlilik hissediyorum.

ÜN1:Bu çevrimiçi alışveriş websitesi iyi bilinen bir web sitesidir.

ÜN2:Bu çevrimiçi alışveriş websitesi iyi bir itibara sahiptir.

Ün/tanınırlık

ÜN3:Bu çevrimiçi alışveriş websitesi ismine aşinayım.

E-WOM1:İnternetteki ürünler hakkındaki kullanıcı oylarını ve değerlendirmelerini incelerim.

E-WOM2:İnternetten bir ürün almak istediğimde çoğunlukla internetteki kişilerin tavsiyelerini değerlendiririm.

Elektronik

E-WOM3:Bir ürün hakkında bilgi sahibi olmak istediğimde internetteki forumlara ve çevrimiçi toplulukların sayfalarına bakarım.

Ağızdan Ağıza

İletişim

(e-WOM)

E-WOM4:Genel olarak, sosyal ağlarda yer almamın şirketin ürün ve hizmetlerini satın almamda fayda sağladığını düşünürüm.

\subsection{Araştırmanın Veri Toplama ve Analiz Yöntemi}

$\mathrm{Bu}$ çalışmada veri toplama aracı olarak anket yöntemi kullanılmıştır. Anket izni için Aydın Adnan Menderes Üniversitesi Etik kuruluna başvurulmuş ve uygulama izni alınmıştır. Anket formu Google Formlar yardımı ile oluşturulmuştur. Covid 19 pandemi sürecinde 
gerçekleştirilen bu araştırmada analize dahil edilen tüm anketler çevrim içi olarak elde edilmiştir.

Anket formunun ilk sorusu katılımcıların daha önce e-ticaret web sitelerinden alışveriş yapıp yapmadıklarıdır. Hiç alışveriş yapmamış olan katılımcıların anketi sonlandırılmıştır. Alışveriş yapmış olan katılımcıların ise en çok alışveriş yaptıkları e-ticaret pazaryerini (trendyol, hepsiburada, n11, gittigidiyor, amazon, akakçe vb.) düşünerek soruları cevaplamaları istenmiştir.

Analiz aşamasında öncelikle örneklemden elde edilen veriler doğrultusunda katılımcıların demografik özellikleri ortaya konulmuş ve ölçeklerin öngörülen yapılarının toplanan veri ile desteklenip desteklenmediği belirlemek için AMOS 20 programı ile doğrulayıcı faktör analizi gerçekleştirilmiştir. Daha sonra ölçeklerin geçerlilikleri, güvenilirlikleri ve korelasyonları ortaya konulmuştur. $\mathrm{Bu}$ aşamadan sonra ise ölçekler arasındaki nedensel ilişkiler yapısal eşitlik modeli ile incelenmiştir. Son olarak, araştırma ölçüm modelinin ölçüm denklik testleri yapılmış ve ölçüm denkliği bulunduktan sonra çoklu grup analizi ile araştırma modelinin kadın ve erkek gruplarda nasıl farklılaştığı araştırılmıştır.

\subsection{Araştırmanın Ana kütlesi ve Örneklemi}

Türkiye'nin Haziran ayı itibariyle 64.400 .000 adet internet kullanıcısı bulunmaktadır. 16-64 yaş arası internet kullanıcılarının ise \%63'ü ayda en az bir defa online alışveriş yapmaktadır. Buna göre yaklaşık olarak 40.572.000 kişinin e-ticaret web sitelerinden ayda en az bir defa alışveriş yaptıkları söylenebilmektedir (Social, 2020).

$\mathrm{Bu}$ araştırmanın ana kütlesi Türkiye'de e-ticaret web sitelerinden alışveriş yapan kullanıc1lardır. (Yazıcıoğlu ve Erdoğan, 2004)'a göre ana kütle sayısı 1.000.000'dan fazla olduğunda ve $+-0,05$ örnekleme hatası ile analiz sonucu elde edilmek istenildiğinde ulaşılması gereken anket sayısı en az 384'dür. Bu araştırmanın örneklemi basit tesadüfi örnekleme metodu ile elde edilmiştir. Araştırmanın örneklemi 400 kişiden oluşmaktadır. Buna göre elde edilen anket sayısının gerçekleştirilecek analizler için yeterli miktarda olduğu söylenebilmektedir.

\section{Bulgular}

\subsection{Katılımcıların Demografik Özellikleri}

$\mathrm{Bu}$ bölümde katılımcıların demografik özellikleri incelenmiştir. Tablo 2'de de görüldüğü üzere ankete katılanların çoğunluğu \%56,5 ile kadınlardır. Ankete katılan kişilerin çoğunluğunun eğitim seviyesi \%63,2 ile lisans (üniversite) eğitimidir. Bu oranı \% 21,5 ile lise, $\% 8,5$ ile yüksekokul, \%5,3 ile yüksek lisans ve \%1,5 ile doktora seviyesi takip etmektedir. Ankete katılanların çoğunluğunun yaş aralığı \%71 oranı ile $18-25$ yaş grubudur. Bu oranı \%18,2 
ile 26-33 yaş aralığı, \%5,5 ile 34-41 yaş aralığı, \%3,3 ile 42-49 yaş aralığ1 ve $\% 2$ ile 50+ yaş aralığı takip etmektedir. Ankete katılım gösteren kişilerin çoğunluğu \% 45,5 ile her gün, \%27,5 oranı ile her ay ve $\% 27$ oranı ile her hafta bilgisayar kullanmaktadır. Ankete katılım gösteren kişilerin çoğunluğu \%99,8 oranı ile her gün ve \%0,2 oranı ile her ay cep telefonu kullanmaktadır.

Tablo 2. Katılımcıların demografik özellikleri

\begin{tabular}{|c|c|c|c|c|}
\hline \multirow{4}{*}{ 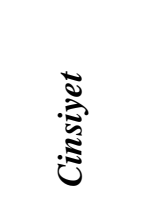 } & & Frekans & $\%$ & Kümülatif \% \\
\hline & Erkek & 174 & 43,5 & 43,5 \\
\hline & Kadın & 226 & 56,5 & 100 \\
\hline & Toplam & 400 & 100 & \\
\hline \multirow{6}{*}{ 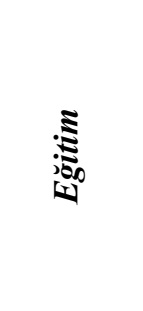 } & Lise & 86 & 21,5 & 21,5 \\
\hline & Yüksekokul & 34 & 8,5 & 30 \\
\hline & Lisans & 253 & 63,2 & 93,3 \\
\hline & Yüksek Lisans & 21 & 5,3 & 98,6 \\
\hline & Doktora & 6 & 1,5 & 100 \\
\hline & Toplam & 400 & 100 & \\
\hline \multirow{6}{*}{ 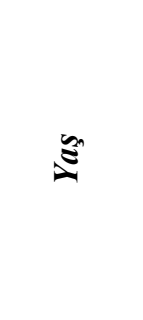 } & $18-25$ & 284 & 71 & 71 \\
\hline & $26-33$ & 73 & 18,2 & 89,3 \\
\hline & $34-41$ & 22 & 5,5 & 94,8 \\
\hline & $42-49$ & 13 & 3,3 & 98 \\
\hline & $50+$ & 8 & 2 & 100 \\
\hline & Toplam & 400 & 100 & \\
\hline \multirow{4}{*}{ 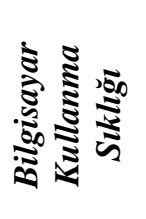 } & Her gün & 182 & 45,5 & 45,5 \\
\hline & Her hafta & 108 & 27 & 72,5 \\
\hline & Her ay & 110 & 27,5 & 100 \\
\hline & Toplam & 400 & 100 & \\
\hline \multirow{3}{*}{ ن } & Her gün & 399 & 99,8 & 99,8 \\
\hline & Her ay & 1 & 0,2 & 100 \\
\hline & Toplam & 400 & 100 & \\
\hline
\end{tabular}

\subsection{Doğrulayıcı Faktör Analizi}

Doğrulayıcı faktör analizi (DFA); önceden geliştirilmiş, önceki araştırmalarda kullanılmış veya teorik bir temeli bulunan bir ölçeğin ya da bir modelin doğruluğunu yeni araştırmalarda ve yeni verilerle doğrulayabilmek niyetiyle kullanılmaktadır (Gürbüz, 2019). DFA analizinde her bir gözlenen değişkenin hangi gizil değişkenin veya faktörün altında yer aldığı bilinmektedir. DFA analizinin sonucunda gözlenen değişkenlerin yük katsayıları, faktörlerin ayrı ayrı açıkladıkları varyans oranı gibi bilgilere ek olarak oluşturulan modelin doğruluğu literatürde kabul edilen çeşitli uyum iyiliği değerleri ile test edilmektedir. $\mathrm{Bu}$ bölümde araştırma modeli (araştırmada yer alan tüm ölçekler) bir bütün halinde analize dahil edilmiştir. 
$\mathrm{Bu}$ araştırmada yer alan tüm verilerin normal dağılım göstermesi nedeniyle maksimum olabilirlik yöntemi kullanılmıştır. (Kline, 2016)'a göre (aktaran: Kılıç \& Koyuncu, 2017, s. 417) "DFA çalışmalarında en azından $\chi 2$, serbestlik derecesi, p-manidarlık değeri, Hata Kareleri Ortalamalarının Karekökü (Root Mean Square Error Of Approximation-RMSEA) ve \%90 güven aralığı, Karşılaştırmalı Uyum İndeksi (Comparative Fit Index-CFI) ve Artık Kareler Ortalamasının Standartlaştırılmış Karekökü (Standardized Root Mean Square Residual-SRMR) değerleri raporlanmalıdır". DFA analizi sonucunda uyum iyiliği değerleri $\left(\mathrm{X}^{2}[341\right.$, $\mathrm{N}=400]=980,865 ; \quad \mathrm{p}<0,01 ; \quad \mathrm{X}^{2} / \mathrm{sd}=2,876 ; \quad \mathrm{CFI}=0,92 \quad(>\mathbf{0 , 0 9}) ; \quad \operatorname{RMSEA}=0,069 \quad(<\mathbf{0 , 0 8})$; SRMR=0,04 $(<\mathbf{0 , 0 8}))$ olarak bulunmuştur. Elde edilen sonuçlara göre uyum iyiliği değerlerinin kabul edilen sınırlar içinde olduğu görülmektedir. Şekil 2'de doğrulayıcı faktör analizi modeli gösterilmektedir.

Şekil 2. Doğrulayıcı faktör analizi modeli

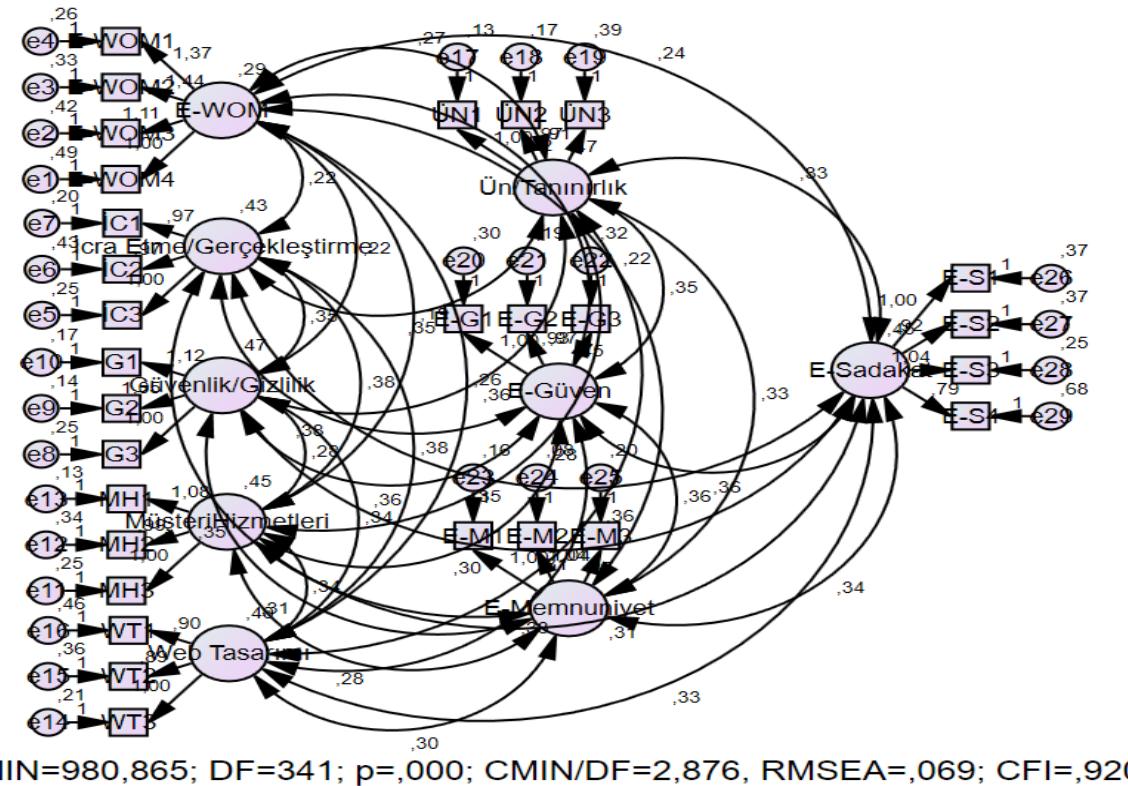

Şekil 2'de gösterilen araştırma modeline ait doğrulayıcı faktör analizi sonuçları Tablo 3'de özetlenmiştir.

Tablo 3. Uyum iyiliği sonuçları ve beklenen değerler

\begin{tabular}{ccccccc} 
& $\mathbf{X}^{\mathbf{2}}$ & $\mathbf{D F}$ & $\mathbf{X}^{2} / \mathbf{s d}$ & $\mathbf{C F I}$ & SRMR & RMSEA \\
\hline $\begin{array}{c}\text { Uyum } \\
\text { iyiliği } \\
\text { değerleri }\end{array}$ & 980,865 & 341 & 2,876 & 0,920 & 0,040 & 0,069 \\
\hline $\begin{array}{c}\text { Beklenen } \\
\text { Değerler }\end{array}$ & - & - & $<\mathbf{5}$ & $>\mathbf{0 , 9 0}$ & $<\mathbf{0 , 0 8}$ & $<\mathbf{0 , 0 8}$ \\
\hline
\end{tabular}

DFA analizinden sonra araştırma modelinin geçerliliği incelenecektir. Birinci düzey çok faktörlü bir araştırma modelinin DFA analizi sonucunda kabul edilebilir sınırlar içinde olması ölçekte yer alan faktörlerin ve faktörlere ait maddelerin belirli bir seviyede ayrışım ve birleşim 
geçerliliğine sahip olduğu anlamına gelmektedir. Ancak araştırmacılar zaman zaman bu kavramları ayrı olarak raporlamayı tercih edebilmektedirler (Gürbüz, 2019, s. 77). Buna bilgiler 1şığında AVE, CR, Cronbach alpha değerleri ve değişkenler arasındaki ilişkilerin yönünü ve gücünü ifade eden korelasyon tablosu Tablo 4'de verilmiştir. AVE ortalama açıklanan varyansı ve CR birleşik yapı güvenilirliğini ifade etmektedir. Cronbach alpha güvenilirlik katsayısı $(\alpha)$ her bir ölçeğin güvenirlirliğini ifade ederken, korelasyon katsayıları faktörler arasındaki ilişkilerin gücünü ve yönünü göstermektedir.

Tablo 4. Ölçeklerin geçerlilikleri, cronbach alpha güvenilirlik katsayısı ve korelasyonlar

\begin{tabular}{|c|c|c|c|c|c|c|c|c|c|c|c|c|}
\hline & AVE & CR & $\begin{array}{l}\text { Cronbach } \\
\text { alpha }(\alpha)\end{array}$ & \begin{tabular}{|c|} 
(E- \\
WOM)
\end{tabular} & (IC) & (SE) & (MH) & $(\mathbf{W T})$ & (ت̈N) & (E-G) & (E-M) & (E-S) \\
\hline E-Wom (E-WOM) & 0,538 & 0,820 & 0,816 & 1,000 & & & & & & & & \\
\hline İcra Etme (İC) & 0,506 & 0,710 & 0,809 &, $525 * *$ & 1,000 & & & & & & & \\
\hline Güvenlik/Gizlilik(G) & 0,741 & 0,790 & 0,895 &, $520 * *$ &, $652 * *$ & 1,000 & & & & & & \\
\hline Müșteri Hizmetleri (MH) & 0,670 & 0,750 & 0,859 & $443^{* *}$ &, $714^{* *}$ &, $536^{* *}$ & 1,000 & & & & & \\
\hline Web Tasarımı (WT) & 0,514 & 0,650 & 0,753 &, $606 * *$ &, $730 * *$ &, $631^{* *}$ &, $652 * *$ & 1,000 & & & & \\
\hline Ün/tanınırlık (ÜN) & 0,670 & 0,750 & 0,848 &, $627 * *$ &, $638 * *$ &, $651 * *$ &, $499 * *$ &, $641^{* *}$ & 1,000 & & & \\
\hline E-Güven (E-G) & 0,612 & 0,720 & 0,825 &, $509 * *$ &, $702 * *$ &, $671 * *$ &, $576 * *$ &, $608 * *$ &, $612 * *$ & 1,000 & & \\
\hline E-Memnuniyet (E-M) & 0,733 & 0,790 & 0,887 & $614^{* *}$ &, $738^{* *}$ &, $648^{* *}$ &, $596^{* *}$ &, $634^{* *}$ &, $680 * *$ &, $744^{* *}$ & 1,000 & \\
\hline E-Sadakat (E-S) & 0,498 & 0,800 & 0,786 &, $529 * *$ &, $645^{* *}$ &, $577 * *$ &, $563^{* *}$ &, $602^{* *}$ &, $589^{* *}$ &, $660^{* *}$ &, $703 * *$ & 1,000 \\
\hline
\end{tabular}

Tablo 4'te her bir değişken için CR>AVE ve Cronbach alpha güvenilirlik katsayısı $(\alpha)>0,70$ olduğu görülmektedir. Tablo 4'de faktörler arası ilişkilere de yer verilmektedir. Korelasyon tablosu incelendiğinde tüm faktörler arasında anlamlı ve pozitif ilişkiler olduğu görülmektedir. Ayrıca pek çok değişken arasında güçlü bir ilişkinin (yükssek korelasyon) olduğu görülmektedir (korelasyon katsayısı $(r)>0,600)$.

\subsection{Yapısal Eşitlik Modeli}

Yapısal eşitlik modeli (YEM) analizlerinde değişkenler arasındaki nedensel ilişkileri incelenmektedir. YEM analizlerinde her bir gizil değişken, gözlenen değişkenlerle (anket maddeleri) ile birlikte YEM analizine dahil edilerek araştırma modelini oluşturmaktadır. YEM analiz sonuçları, gözlenen değişkenlerin ölçüm hatalarını da içerdiğinden, değişkenler arasındaki neden-sonuç ilişkileri diğer analiz sonuçlarına göre daha güvenilir olarak kabul edilmektedir (Gürbüz, 2019, s. 94). Araştırmanın bu bölümünde değişkenler arasındaki nedensel ilişkileri tespit edebilmek için yapısal eşitlik modeli kurulmuştur.

\section{Şekil 3. Yapısal modele ait standardize yol katsayıları}




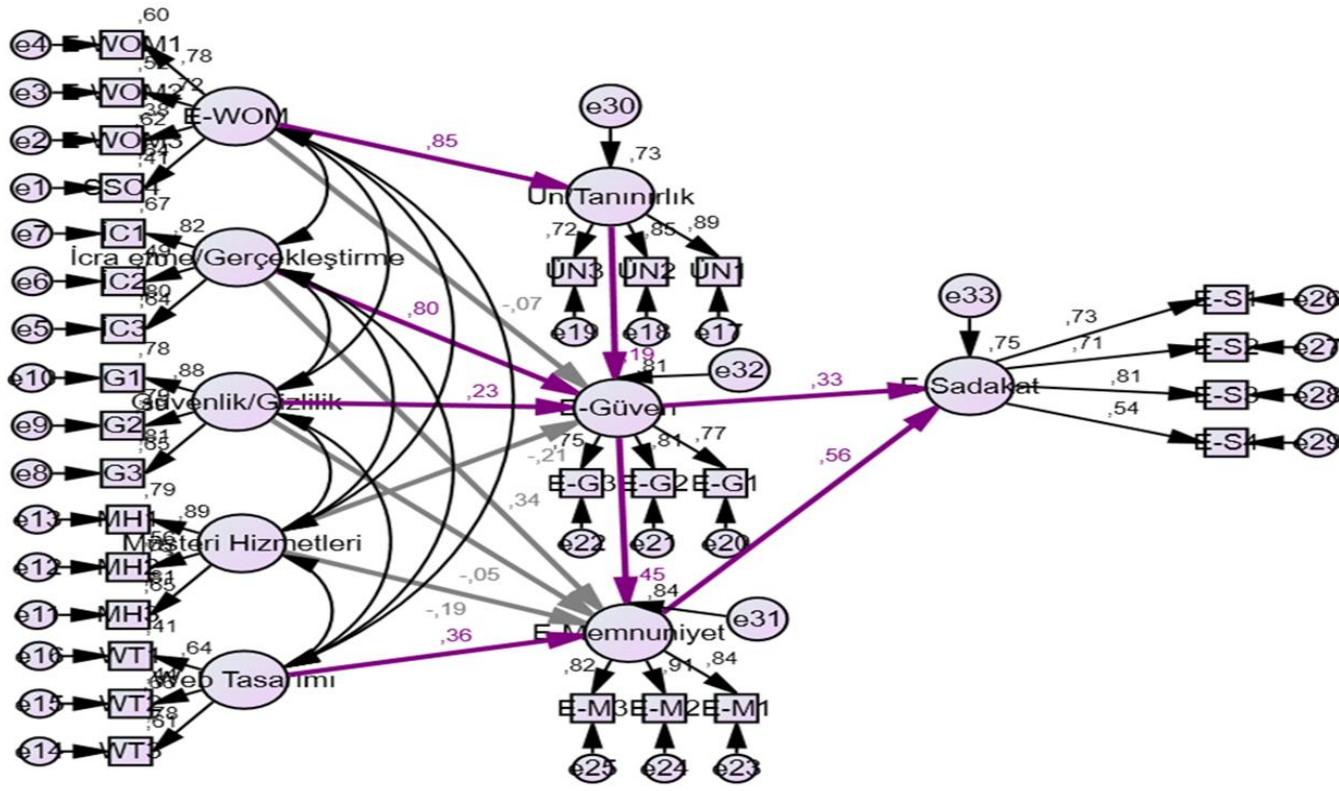

CMIN=1131,400; DF=354; $p=, 000 ; C M I N / D F=3,196$, RMSEA $=, 074 ; G F I=, 835 ; C F I=, 903$

Şekil 3'de bu çalışmaya ait YEM analizi sonuçları gösterilmektedir. Şekil 3'deki mor renkle gösterilen oklar anlamlı nedensel ilişkilere işaret ederken, gri renkli oklar anlamsız nedensel ilişkileri ifade etmektedir. Öncelikle araştırma modelinin kabul edilebilir bir uyum iyiliğine sahip olduğu söylenebilmektedir $\left(\mathrm{X}^{2}[354, \mathrm{~N}=400]=1131,400 ; \mathrm{p}<0,01 ; \mathrm{X}^{2} / \mathrm{sd}=3,196\right.$; CFI=0,903 (>0,09); RMSEA=0,074 (<0,08); SRMR=0,053 $(<\mathbf{0 , 0 8}))$. Ancak Şekil 3'e göre müşteri hizmetleri değişkenine ait tüm hipotezlerin geçersiz olduğu görülmektedir. Nedensel ilişkilere herhangi bir katkı sağlamayan müşteri ilişkileri faktörü ve diğer faktörlere ait olan tüm anlamsız hipotezler modelden çıkarılıp yol analizi yinelenmiştir. Anazliz yinelendiğinde şekil 4'deki yeni model oluşmuştur. Şekil 4'de yeni araştırma modelinin uyum iyiliği değerleri ve nihai değişkenler arasındaki nedensel ilişkiler gösterilmektedir. 


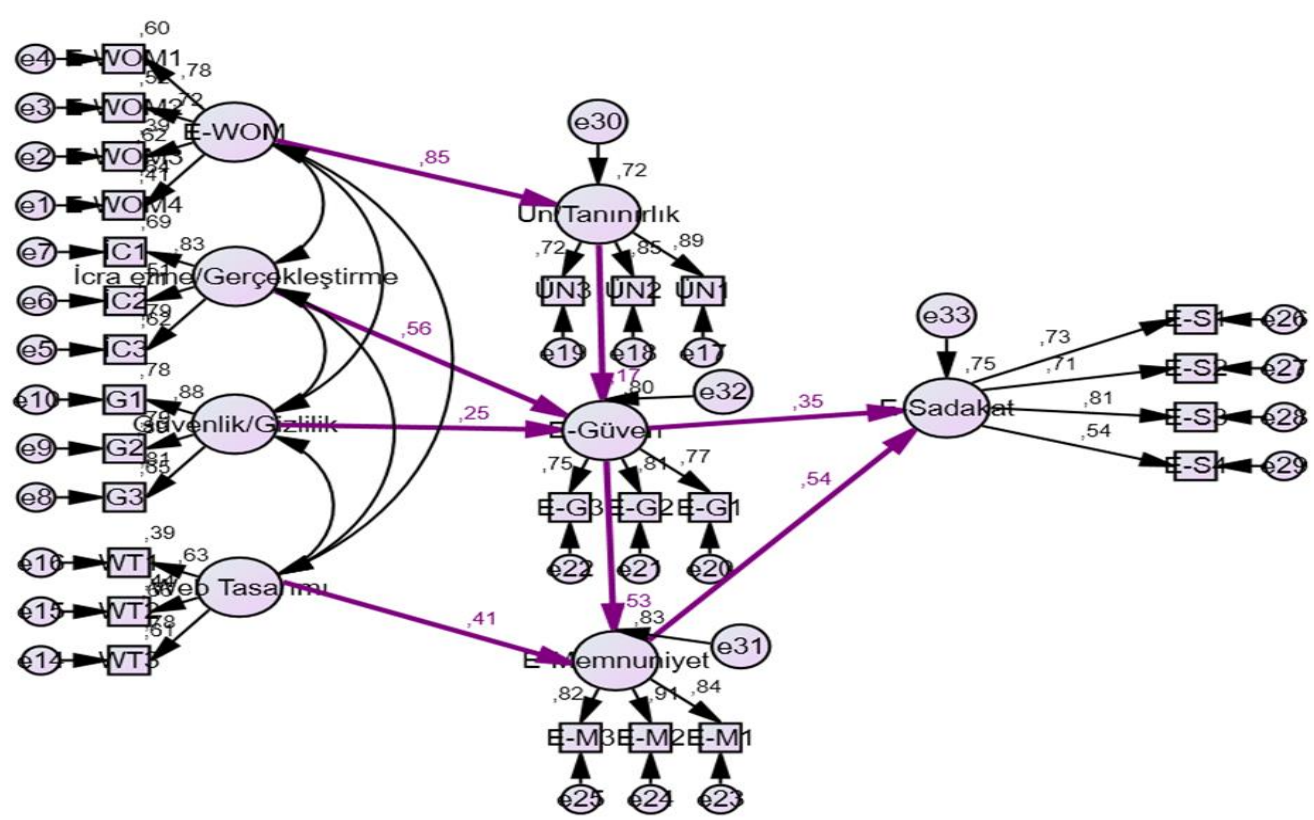

$\mathrm{CMIN}=906,884 ; \mathrm{DF}=285 ; \mathrm{p}=, 000 ; \mathrm{CMIN} / \mathrm{DF}=3,182, \mathrm{RMSEA}=, 074 ; \mathrm{GFI}=, 849 ; \mathrm{CFI}=, 911$

Şekil 4'de de mor renkli oklar anlamlı nedensel ilişkilere işaret ederken, gri renkli oklar anlamsız nedensel ilişkileri ifade etmektedir. Müşteri hizmetleri değişkenin ve diğer faktörlere ait olan diğer anlamsız hipotezlerin yer almadığı yeni araştırma modeli kabul edilebilir uyum iyiliği değerlerine sahiptir $\left(\mathrm{X}^{2}[285, \mathrm{~N}=400]=906,884 ; \mathrm{p}<0,01 ; \mathrm{X}^{2} / \mathrm{sd}=3,182 ; \mathrm{CFI}=0,911\right.$ $(>\mathbf{0 , 0 9})$; RMSEA=0,074 $(<\mathbf{0 , 0 8}) ;$ SRMR=0,052 $(<\mathbf{0 , 0 8}))$.

Yeni YEM analizi sonuçlarına göre; modelde yer alan tüm hipotezler kabul edilmiştir. Benzer şekilde eWOM'un web sitenin ünü/tanınırlığı üzerindeki etkisinin anlamlı ve pozitif $(\beta=0,85, \mathrm{p}<0,01)$, icra etme/gerçekleştirmenin e-güven üzerindeki etkisinin anlamlı ve pozitif $(\beta=0,56, p<0,01)$, güvenlik/gizliliğin e-güven üzerindeki etkisinin anlamlı ve pozitif $(\beta=0,25$, $\mathrm{p}<0,01)$, web tasarımının e-memnuniyet üzerindeki etkisinin anlamlı ve pozitif $(\beta=0,41$, $\mathrm{p}<0,01)$, web sitesinin ünü/tanınırlığının e-güven üzerindeki etkisinin anlamlı ve pozitif $(\beta=0,17, p<0,01)$, e-güvenin e-memnuniyet üzerindeki etkisinin anlamlı ve pozitif $(\beta=0,53$, $\mathrm{p}<0,01)$, e-güvenin e-sadakat üzerindeki etkisinin anlamlı ve pozitif $(\beta=0,35, p<0,01)$ ve ememnuniyetin e-sadakat üzerindeki etkisinin etkisinin anlamlı ve pozitif $(\beta=0,54, p<0,01)$ olduğu bulunmuştur. YEM analizine ilişkin tüm parametre tahmin değerleri Tablo 5'te sunulmaktadir. 
Tablo 5. YEM analizine ilişkin parametre tahmin değerleri

\begin{tabular}{|c|c|c|c|c|c|c|}
\hline \multicolumn{3}{|c|}{ Parametre Tahminleri } & \multirow{2}{*}{$\begin{array}{c}\text { Standardize B } \\
0,639\end{array}$} & \multirow{2}{*}{$\begin{array}{c}\begin{array}{c}\text { Standardize } \\
\text { olmayan B }\end{array} \\
1,000\end{array}$} & \multirow[t]{2}{*}{$\begin{array}{c}\text { Standart } \\
\text { Hata }\end{array}$} & \multirow[t]{2}{*}{$\mathbf{P}$} \\
\hline E-WOM4 & $<---$ & E-WOM & & & & \\
\hline E-WOM3 & $<---$ & E-WOM & 0,622 & 0,969 & 0,09 & $* * *$ \\
\hline E-WOM2 & $<---$ & E-WOM & 0,724 & 1,231 & 0,10 & $* * *$ \\
\hline E-WOM1 & $<---$ & E-WOM & 0,776 & 1,235 & 0,10 & $* * *$ \\
\hline İC3 & $<---$ & İcra etme & 0,790 & 1,000 & & \\
\hline İC2 & $<---$ & İcra etme & 0,711 & 0,995 & 0,07 & $* * *$ \\
\hline İC1 & $<---$ & İcra etme & 0,831 & 0,989 & 0,06 & $* * *$ \\
\hline G3 & $<---$ & Güvenlik/Gizlilik & 0,808 & 1,000 & & \\
\hline $\mathrm{G} 2$ & $<---$ & Güvenlik/Gizlilik & 0,889 & 1,044 & 0,05 & $* * *$ \\
\hline G1 & $<---$ & Güvenlik/Gizlilik & 0,884 & 1,118 & 0,06 & $* * *$ \\
\hline WT3 & $<---$ & Web Tasarımı & 0,784 & 1,000 & & \\
\hline WT2 & $<---$ & Web Tasarımı & 0,660 & 0,879 & 0,06 & $* * *$ \\
\hline WT1 & $<---$ & Web Tasarımı & 0,626 & 0,902 & 0,07 & $* * *$ \\
\hline ÜN1 & $<---$ & Ün/tanınırlık & 0,885 & 1,000 & & \\
\hline ÜN2 & $<---$ & Ün/tanınırlık & 0,847 & 0,963 & 0,05 & $* * *$ \\
\hline ÜN3 & $<---$ & Ün/tanınırlık & 0,719 & 0,927 & 0,06 & $* * *$ \\
\hline E-T1 & $<---$ & E-Güven & 0,766 & 1,000 & & \\
\hline E-T2 & $<---$ & E-Güven & 0,812 & 0,927 & 0,06 & $* * *$ \\
\hline E-T3 & $<---$ & E-Güven & 0,746 & 0,970 & 0,06 & $* * *$ \\
\hline E-M1 & $<---$ & E-Memnuniyet & 0,836 & 1,000 & & \\
\hline E-M2 & $<---$ & E-Memnuniyet & 0,908 & 1,044 & 0,05 & $* * *$ \\
\hline E-M3 & $<---$ & E-Memnuniyet & 0,815 & 1,039 & 0,05 & $* * *$ \\
\hline E-S1 & $<---$ & E-Sadakat & 0,730 & 1,000 & & \\
\hline E-S2 & $<---$ & E-Sadakat & 0,705 & 0,926 & 0,07 & $* * *$ \\
\hline E-S3 & $<---$ & E-Sadakat & 0,811 & 1,049 & 0,07 & $* * *$ \\
\hline E-S4 & $<---$ & E-Sadakat & 0,540 & 0,802 & 0,08 & $* * *$ \\
\hline \multicolumn{7}{|l|}{ Yapisal Model } \\
\hline Ün/tanınırlık & $\begin{array}{ll}<-- \\
\end{array}$ & E-WOM & $\mathbf{0 , 8 5 0}$ & 1,031 & 0,08 & $* * *$ \\
\hline E-Güven & $<---$ & İcra etme & 0,561 & 0,567 & 0,08 & $* * *$ \\
\hline E-Güven & $<---$ & Güvenlik/Gizlilik & 0,252 & 0,242 & 0,06 & $* * *$ \\
\hline E-Güven & $<---$ & Ün/tanınırlık & $\mathbf{0 , 1 7 1}$ & 0,165 & 0,05 & 0,001 \\
\hline E-Memnuniyet & $<---$ & Web Tasarımı & 0,412 & 0,406 & 0,09 & $* * *$ \\
\hline E-Memnuniyet & $<---$ & E-Güven & 0,534 & 0,491 & 0,09 & $* * *$ \\
\hline E-Sadakat & $<---$ & E-Güven & 0,347 & 0,346 & 0,12 & 0,004 \\
\hline E-Sadakat & $<---$ & E-Memnuniyet & 0,543 & 0,589 & 0,13 & $* * *$ \\
\hline & & & \multicolumn{4}{|c|}{$\mathbf{R}^{2}$} \\
\hline$\ddot{U} n /$ tanınırlık & <--- & $E-W O M$ & \multicolumn{4}{|c|}{0,723} \\
\hline E-Güven & $<--$ & $\begin{array}{c}\text { Ícra etme, } \\
\text { Güvenlik/Gizlilik, } \\
\text { Ün/tanınırlık }\end{array}$ & \multicolumn{4}{|c|}{0,796} \\
\hline E-Memnuniyet & $<--$ & $\begin{array}{c}\text { Web Tasarımı, } E \text { - } \\
\text { Güven }\end{array}$ & \multicolumn{4}{|c|}{0,827} \\
\hline E-Sadakat & <-- & $\begin{array}{l}\text { E-Güven, E- } \\
\text { Memnuniyet }\end{array}$ & \multicolumn{4}{|c|}{0,749} \\
\hline
\end{tabular}

Bu bulgulara ek olarak e-WOM değişkeni web sitenin ünü/tanınırlığı değişkenin varyansının \%72'sini açıklanmaktadır. İcra etme/gerçekleştirme, güvenlik/gizlilik ve web sitesinin ünü/tanınırlığı değişkenleri e-güven değişkeninin varyansının \%80'unu açıklamaktadır. Web tasarımı ve e-güven değişkenleri e-memnuniyet değişkeninin varyansının \%83'sini açıklamaktadır. Son olarak e-güven ve e-memnuniyet değişkenleri e-sadakat 
değişkeninin varyansının \%75'ünü açıklamaktadır. Tüm bu bulgular ışığında Tablo 6'daki hipotez tablosu oluşturulmuştur.

Tablo 6. Hipotez testi sonuçları

\begin{tabular}{lc}
\multicolumn{1}{c}{ Hipotezler } & Kabul/Red \\
\hline H1a: e-WOM, web sitesinin ünü/tanınırlı̆̆ını anlamlı ve pozitif olarak etkilemektedir. & KABUL \\
\hline H1b: e-WOM, e-güveni anlamlı ve pozitif olarak etkilemektedir. & RED \\
\hline H2a: İcra etme/gerçekleştirme, e-güveni anlamlı ve pozitif olarak etkilemektedir. & KABUL \\
\hline H2b: İcra etme/gerçekleştirme, e-memnuniyeti anlamlı ve pozitif olarak etkilemektedir. & RED \\
\hline H3a: Güvenlik/gizlilik, e-güveni anlamlı ve pozitif olarak etkilemektedir. & KABUL \\
\hline H3b: Güvenlik/gizlilik, e-memnuniyeti anlamlı ve pozitif olarak etkilemektedir. & RED \\
\hline H4a: Müşteri hizmetleri, e-güveni anlamlı ve pozitif olarak etkilemektedir. & RED \\
\hline H4b: Müşteri hizmetleri, e-memnuniyeti anlamlı ve pozitif olarak etkilemektedir. & RED \\
\hline H5:Web tasarımı, e-memnuniyeti anlamlı ve pozitif olarak etkilemektedir. & KABUL \\
\hline H6: Web sitesinin ünü/tanınırlı̆̆ı, e-güveni anlamlı ve pozitif olarak etkilemektedir. & KABUL \\
\hline H7a: E-güven, e-memnuniyeti anlamlı ve pozitif olarak etkilemektedir. & KABUL \\
\hline H7b: E-güven, e-sadakati anlamlı ve pozitif olarak etkilemektedir. & KABUL \\
\hline H8: E-memnuniyet e-sadakati anlamlı ve pozitif olarak etkilemektedir. & KABUL \\
\hline
\end{tabular}

Tablo 6'da hipotez testi sonuçları özetlenmektedir. Buna göre H1b, H2b, H3b, H4a ve H4b hipotezleri reddedilirken, H1a, H2a, H3a, H5, H6 ve H7a, H7b ve H8 hipotezleri kabul edilmektedir.

\section{4. Ölçüm Denkliği}

Sosyal bilimler alanında çoğunlukla aynı ölçüm aracı ile farklı insan gruplarının çeşitli açılardan kıyaslanması istenmektedir. Fakat bir ölçüm aracı her bir grup için aynı anlamı ifade edemeyebilmektedir. İdeal olarak bir ölçüm aracının tüm grupları ölçülmek istenen niteliklere yöneltmesi beklenmektedir. Ölçüm aracındaki ölçüm maddeleri ile karşılaştıklarında tüm grupların zihinlerinde benzer kavramlar oluşmalıdır. Ancak anket maddeleri için grupların kendilerine has cevapları olması beklenmektedir. Bu bağlamda bir kavram gruplar arasında kıyaslanmadan önce, olası farklılığın ölçüm aracından $\mathrm{m} 1$ yoksa grup özelliklerinden mi kaynaklandığının tespit edilmesi gerekmektedir (Gürbüz, 2019, s. 161). Bu ise ölçme aracına ölçüm denkliği testleri yapılarak sağlanabilmektedir. Ölçüm denkliği sağlanan bir ölçme aracının tüm grupların zihinlerinde aynı kavramı ifade ettiği ve farklılıkların tamamen grupların özelliklerinden kaynaklandığı söylenebilmektedir. Ölçüm denkliği sağlanan bir ölçüm aracındaki gruplar arasındaki farklılıkların tespit edilebilmesi için çoklu grup analizinin yapılması gerekmektedir. Bir diğer ifadeyle ölçüm denkliği sağlanan ölçekler için çoklu grup analizi gerçekleştirilebilmektedir.

Ölçüm denkliğini tespit edebilmek için dört adet denklik türünün sağlanması gerekmektedir. $\mathrm{Bu}$ denklik türleri sırasıyla yapısal denklik (configural invariance), metrik 
denklik (metric/weak/pattern invariance), ölçek denkliği (scalar/strong invariance) ve katı denklik (residual/strict invariance)'dir.

Yapısal denklik; bir ölçeğin faktör yapısının gruplar arasındaki benzerliğini ifade etmektedir. Bir ölçeğin yapısal denkliği bulunuyorsa, ölçüm modelinde yer alan tüm maddeler her grupta kendilerine ait olan aynı faktörlere yüklenmelidir. Yapısal denkliğin tespit edilmesi için DFA analizi yapılmaktadır. DFA analizi sonucunda uyum iyiliği değerleri sınır değerler arasında ise yapısal denklik sağlanmış demektir. Yapısal denklik kurulmadan ölçüm denkliği sağlanamamaktadır (Gürbüz, 2019, s. 161).

Metrik denklik, bir ölçüm aracında yer alan ölçüm maddelerinin faktör yük değerlerinin tüm gruplarda benzer değerlere sahip olmasıdır. Yapısal model (unconstrained) ve metrik denkliği (measument weights) modelleri kendi aralarında $\Delta \chi 2$ ve $\Delta$ CFI testleri ile karşılaştırılır. İki modele ait $\Delta \chi 2$ farkl11ık testinin anlamsız olması $(\Delta \chi 2$ ait $\mathrm{p}>0,05)$ ya da iki model arasındaki CFI farkının 0,01 'den küçük olması $(\triangle \mathrm{CFI}<0,01)$ durumunda metrik denklik sağlanmaktadır (Gürbüz, 2019, s. 164).

Ölçek denkliği, faktörlerdeki madde sabitlerinin (measurement intercepts) gruplar arasında eşdeğer olup olmadığını ifade eder. Metrik model (measument weights) ve ölçek denkliği (measument intercepts) modeli kendi aralarında $\Delta \chi 2$ ve $\Delta$ CFI testleri ile karşılaştırılmaktadır. $\Delta \chi 2$ farklılık testinin anlamsız olması $(\Delta \chi 2$ ait $\mathrm{p}>0,05)$ ya da iki model arasındaki CFI farkının 0,01 'den küçük olması $(\Delta \mathrm{CFI}<0,01)$ durumunda ölçek denkliği sağlanmaktadır (Gürbüz, 2019, s. 164).

Katı denklik; maddelere ait hata varyanslarının eş değer olup olmadığını ifade eder. Ölçek denkliği (measument intercepts) ve katı denklik modeli (measurement residuals) kendi aralarında $\Delta \chi 2$ ve $\Delta$ CFI testleri ile karşılaştırılmaktadır. $\Delta \chi 2$ farklılık testinin anlamsız olması $(\Delta \chi 2$ ait $\mathrm{p}>0,05)$ ya da iki model arasındaki CFI farkının 0,01 'den küçük olması $(\Delta \mathrm{CFI}<0,01)$ durumunda katı denklik sağlanmaktadır. Ancak katı denklik türü ölçüm denkliği türleri içinde en katı denklik türü olduğundan araştırmalarda çoğunlukla raporlanmamaktadır (Gürbüz, 2019, s. 166). Hair vd. (2010) ve Kline (2011) sosyal bilimlerde yapılacak grup karşılaştırmalarında ölçmenin en az metrik değişmezlik modeli seviyesinde karşılanması gerektiğini belirtmektedir.

$\mathrm{Bu}$ araştırmada öncelikle yapısal denklik test edilmiştir. Yapısal değişmezlik sonucunda ölçüm modeli veriyle uyum sağlamazsa (model indeksleri anlamsız çıkarsa), ölçüm değişmezliğinin diğer aşamalarına geçilememektedir (Kline, 2011, s. 252). Analiz sonuçlarına göre ölçüm modeline ait sonuçlar $(\chi 2 / \mathrm{df}=2,81$; CFI=0,90; RMSEA=0,068) kabul edilebilir değerlere sahiptir. Diğer bir ifadeyle yapısal değişmezliğin sağlandığı yani faktör yapılarının aynı olduğu (farklılaşmadığı) ifade edilebilir. 
Ölçüm denkliği testlerinde $\Delta \chi 2$ farklılık testlerinin fazla güvenilir olmadığı ve büyük örneklemlerde yanlı sonuçlar vermesi sebebiyle son yıllarda yapılan araştırmalarda $\Delta \chi 2$ farkl111k testlerinin $\left(\Delta \chi^{2}\right.$ ait $\left.\mathrm{p}>0,05\right)$ yerine CFI farkl111k testlerinin $(\Delta \mathrm{CFI}<0,01)$ kullanılması tavsiye edilmektedir (Gürbüz, 2019, s. 180). Buna göre bu çalışmada metrik denklik, ölçek denkliği ve katı denkliği testlerinin CFI farklılık testleri ile araştırılması kararlaştırılmıştır. Analiz sonuçlarına göre; yapısal model (unconstrained) ve metrik denkliği (measument weights) modellerinin CFI değerleri arasındaki fark 0,01 değerinden küçüktür $(\Delta C F I<0,01)$. Metrik model (measument weights) ve ölçek denkliği (measument intercepts) modellerinin CFI değerleri arasındaki fark 0,01 değerinden küçüktür $(\Delta \mathrm{CFI}<0,01)$. Ancak ölçek denkliği (measument intercepts) ve katı denklik (measurement residuals) modellerinin CFI değerleri arasındaki fark ise 0,01 'den büyüktür $(\Delta \mathrm{CFI}>0,01)$. Dolayısıyla söz konusu ölçüm modelinin yapısal, metrik ve ölçek denkliğinin sağlandığı ancak katı denkliğinin sağlanamadığı ifade edilebilmektedir. Hair vd. (2010) ve Kline (2011) çoklu grup analizi yapabilmek için en az metrik denkliğin sağlanması gerektiğini ileri sürmektedir. Buna göre bu ölçüm aracı yapısal, metrik ve ölçek denkliği sağladığı yalnızca katı denkliği sağlamadığı için en az metrik denkliğin sağlanması kriterini yerine getirmektedir. Dolayısı ile gruplar arasındaki farklılıklar çoklu grup analizi ile ölçülebilecektir.

\section{5. Çoklu Grup Analizi}

Bir önceki bölümde ölçüm aracının ölçüm denkliğinin sağlandığı görülmüştür. Buna göre gruplar arasındaki olası farklılıkların grupların kendilerine ait özelliklerinden kaynaklandığı ortaya konulmuştur. Ölçüm denkliği sağlanan bir ölçüm aracındaki gruplar arasındaki farklılıkların tespit edilebilmesi için çoklu grup analizinin (multi-group analysis) yapılmas1 gerekmektedir.

$\mathrm{Bu}$ bölümde cinsiyet olgusunun araştırma modeli üzerinde düzenleyici rolünün olup olmadığını belirlemek için çoklu grup analizi yapılmıştır. Çoklu grup analiziyle araştırma modelinin belirli gruplarda farklılaşıp farklılaşmadığı ve farklılaşıyor ise hangi yönlerden farklılaştığı incelenmiştir (Şimşek, 2007). Bu çalışmada araştırma modelinin erkek ve kadın gruplarındaki farklılaşma durumları incelenmiştir. Sınırlandırılmamış modelin doğru olduğu varsayımına göre oluşturulan model karşılaştırma tablosu çıktılarına göre $\left(\chi^{2}=45,773\right.$; df =26; $\left.\chi^{2} / \mathrm{df}=1,76, \mathrm{p}=0,01<0,05\right)$ değerleri bulunmuş ve $\mathrm{p}<0,05$ olduğundan araştırma modelinin erkek ve kadın gruplarında anlamlı bir fark gösterdiği sonucuna ulaşılmıştır. Buna göre "araştırma modeli cinsiyet gruplarına göre farklılaşmaktadır”. Çoklu grup analiziyle erkek 
grubu için oluşturulan araştırma modeli Şekil 5'de, kadın grubu için oluşturulan araştırma modeli ise Şekil 6'de ele alınmıştır.

\section{Şekil 5. Erkek grubuna ait yol diyagramı}

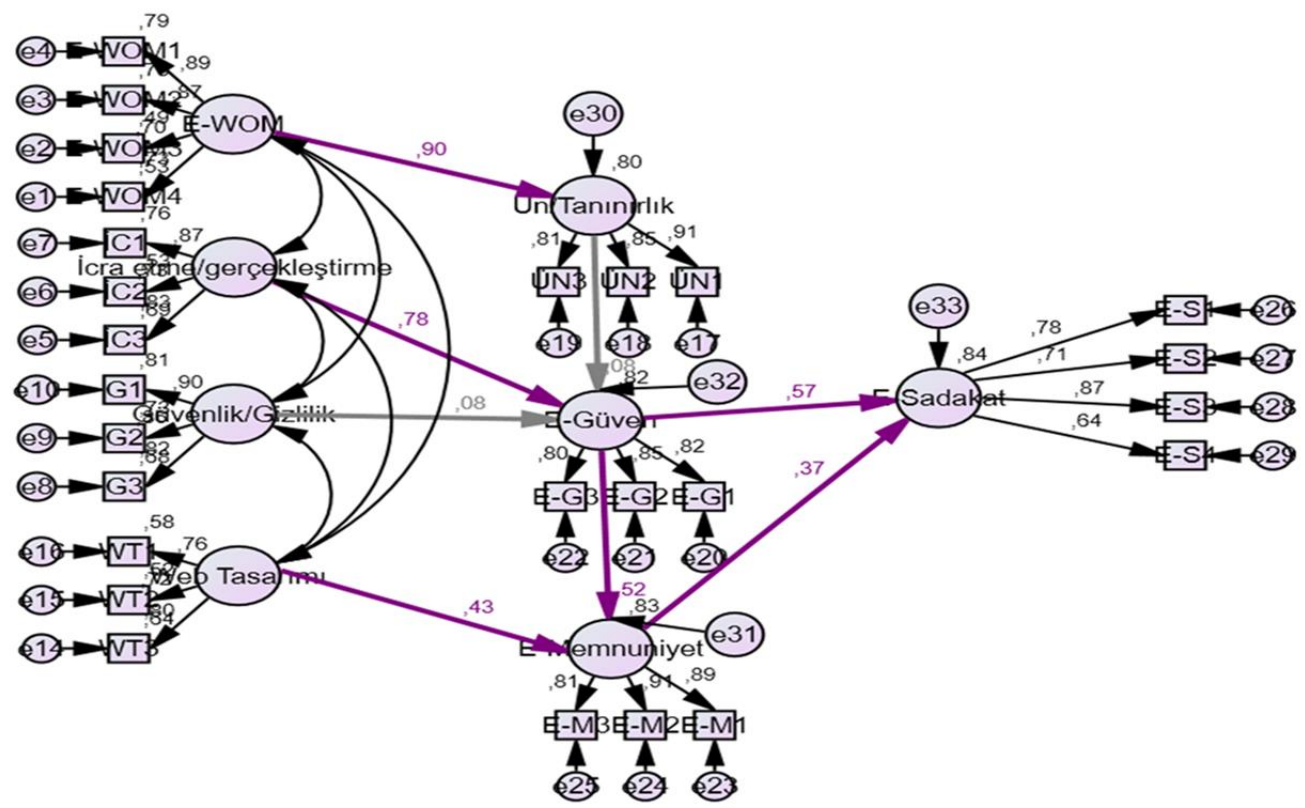

$\mathrm{CMIN}=1524,967 ; \mathrm{DF}=570 ; \mathrm{p}=, 000 ; \mathrm{CMIN} / \mathrm{DF}=2,675, \mathrm{RMSEA}=, 065 ; \mathrm{GFI}=, 773 ; \mathrm{CFI}=, 867$

Şekil 5'de erkek grubu için anlamlı olan yol katsayıları mor oklar ile gösterilmekte iken, anlamlı olmayan yol katsayıları gri renkle gösterilmektedir. Buna göre erkek grubu için; EWOM web sitesinin ün/tanınırlığını anlamlı ve pozitif $(\beta=0,90, \quad p<0,05), \quad$ icra etme/gerçekleştirme e-güveni anlamlı ve pozitif $(\beta=0,78, \mathrm{p}<0,05)$, web tasarımı e-memnuniyeti anlamlı ve pozitif $(\beta=0,43, p<0,05)$, e-güven e-memnuniyeti anlamlı ve pozitif $(\beta=0,52$, $\mathrm{p}<0,05)$, e-güven e-sadakati anlamlı ve pozitif $(\beta=0,57, \mathrm{p}<0,05)$ ve e-memnuniyet e-sadakati anlamlı ve pozitif $(\beta=0,37, \mathrm{p}<0,05)$ olarak etkilemektedir. Ancak güvenlik/gizliliğin e-güven üzerinde anlamlı bir etkisi bulunmamaktadır. Ek olarak web sitesinin ünü/tanınırlığının e-güven üzerinde anlamlı bir etkisi bulunmamaktadır. Ayrıca web sitesinin ünü/tanınırlığındaki değişimin $\left(\mathrm{R}^{2}=0,80\right)$ \%80’i E-WOM değişkeni tarafından açıklanırken, e-güvendeki değişimin $\left(\mathrm{R}^{2}=0,82\right) \quad \% 82$ 'si yalnızca icra etme/gerçekleştirme tarafından açıklanmakta, ememnuniyetteki değişimin $\left(\mathrm{R}^{2}=0,83\right) \% 83$ 'ü, e-güven ve web tasarımı tarafından açıklanmakta ve son olarak e-sadakattaki değişimin $\left(\mathrm{R}^{2}=0,84\right) \% 84$ 'ü, e-güven ve e-memnuniyet tarafından açıklanmaktadır. 


\section{Şekil 6. Kadın grubuna ait yol diyagramı}

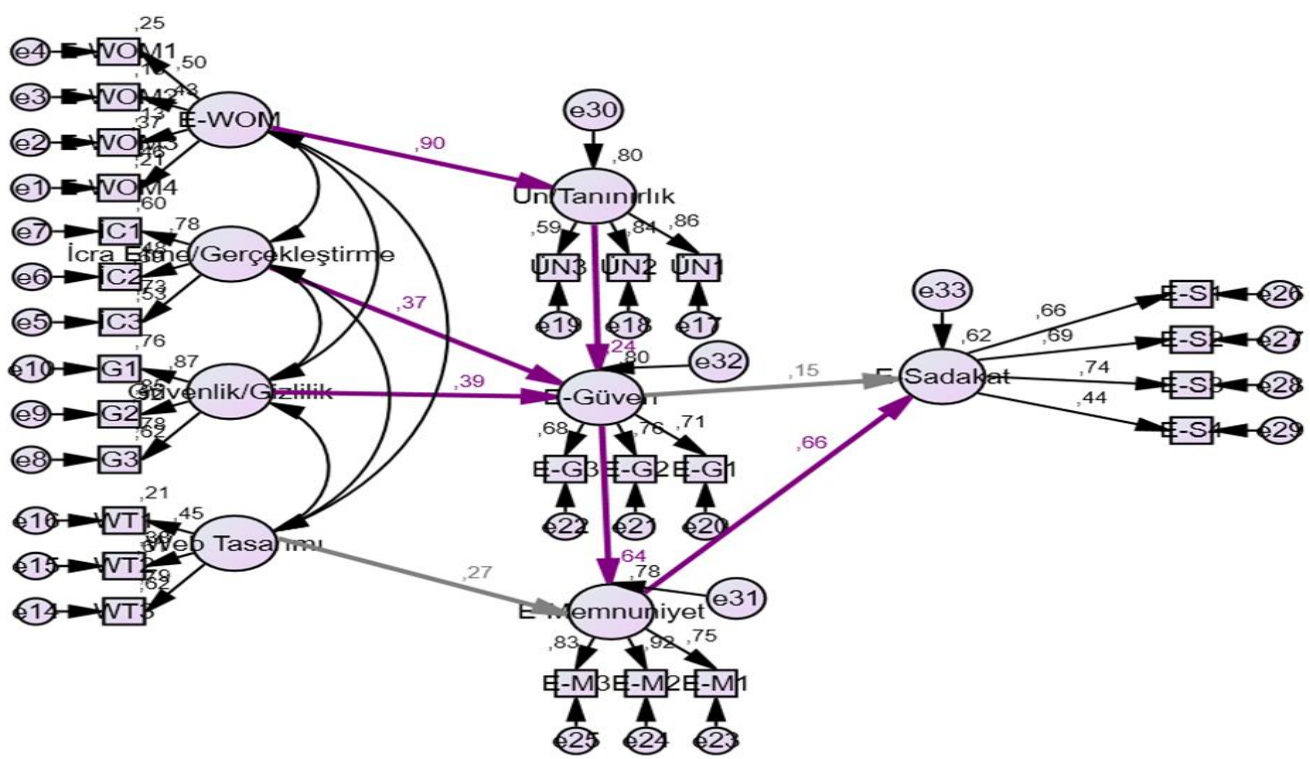

$\mathrm{CMIN}=1524,967 ; \mathrm{DF}=570 ; \mathrm{p}=, 000 ; \mathrm{CMIN} / \mathrm{DF}=2,675, \mathrm{RMSEA}=, 065 ; \mathrm{GFI}=, 773 ; \mathrm{CFI}=, 867$

Şekil 6'da kadın grubu için anlamlı olan yol katsayıları mor oklar ile gösterilmekte iken, anlamlı olmayan yol katsayıları gri okla gösterilmektedir. Buna göre kadın grubu için; E-WOM web sitesinin ünü/tanınırlığını anlamlı ve pozitif $(\beta=0,90, \mathrm{p}<0,05)$, icra etme/gerçekleştirme egüveni anlamlı ve pozitif $(\beta=0,37, \mathrm{p}<0,05)$, güvenlik/gizlilik e-güveni anlamlı ve pozitif $(ß=0,39, \mathrm{p}<0,05)$, web sitesinin ün/tanınırlığı e-güveni anlamlı ve pozitif $(\beta=0,24, \mathrm{p}<0,05)$, egüven e-memnuniyeti anlamlı ve pozitif $(\beta=0,64, \mathrm{p}<0,05)$ ve e-memnuniyet e-sadakati anlamlı ve pozitif $(\beta=0,66, p<0,05)$ olarak etkilemektedir. Ancak web tasarımının e-memnuniyet üzerinde anlamlı bir etkisi bulunmamaktadır. Ek olarak e-güvenin e-sadakat üzerinde anlamlı bir etkisi bulunmamaktadır. Ayrıca web sitesinin ün/tanınırlığındaki değişimin $\left(\mathrm{R}^{2}=0,80\right)$ \%80’i E-WOM değişkeni tarafından açıklanırken, e-güvendeki değişimin $\left(\mathrm{R}^{2}=0,79\right) \% 79$ ’u, web sitesinin ünü/tanınırlığı, icra etme/gerçekleştirme ve güvenlik/gizlilik tarafından açıklanmakta, e-memnuniyetteki değişimin $\left(\mathrm{R}^{2}=0,83\right) \% 83$ 'ü, e-güven tarafından açıklanmakta ve son olarak e-sadakatteki değişimin $\left(\mathrm{R}^{2}=0,62\right) \% 62$ 'si, e-memnuniyet tarafından açıklanmaktadır.

Tablo 7'de yukarıdaki paragraflarda açıklanmış olan araştırma modelinin erkek ve kadın grupları için öngörülen ilişkilerine ait standardize edilmiş yol katsayıları, p değerleri ve hipotez sonuçları özetlenmektedir. 
Tablo 7. Kadın ve erkek gruplarının yol katsayılarının karşılaştırılması

\begin{tabular}{|c|c|c|c|c|c|c|}
\hline & Erkek $(n=174)$ & & & Kadın $(n=226)$ & & \\
\hline Hipotezler & $\begin{array}{c}\text { Standardize Yol } \\
\text { Katsayısı }\end{array}$ & $\mathbf{p}$ & Sonuç & $\begin{array}{c}\text { Standardize } \\
\text { Yol Katsayısı }\end{array}$ & $\mathbf{p}$ & Sonuç \\
\hline E-WOM $\rightarrow$ Ün/tanınırlık & 0,90 & $* * *$ & Kabul & 0,90 & $* * *$ & Kabul \\
\hline İcra etme/Gerçekleștirme $\rightarrow$ E- & 0,78 & $* * *$ & Kabul & 0,37 & $* * *$ & Kabul \\
\hline Güvenlik/Gizlilik $\rightarrow$ E-Güven & 0,08 & 0,484 & Red & 0,39 & $* * *$ & Kabul \\
\hline Web Tasarımı $\rightarrow$ E-Memnuniyet & 0,43 & $* * *$ & Kabul & 0,27 & 0,054 & Red \\
\hline Ün/tanınırlık $\rightarrow$ E-Güven & 0,08 & 0,352 & Red & 0,24 & 0,006 & Kabul \\
\hline E-Güven $\rightarrow$ E-Memnuniyet & 0,52 & 0,013 & Kabul & 0,64 & $* * *$ & Kabul \\
\hline E-Güven $\rightarrow$ E-Sadakat & 0,57 & $* * *$ & Kabul & 0,15 & 0,401 & Red \\
\hline E-Memnuniyet $\rightarrow$ E-Sadakat & 0,37 & $* * *$ & Kabul & 0,66 & $* * *$ & Kabul \\
\hline \multicolumn{7}{|l|}{$R^{2}$} \\
\hline$\ddot{U}$ Ü/tanınırlık & & & 0,802 & & & 0,802 \\
\hline E-Güven & & & 0,822 & & & 0,799 \\
\hline E-Memnuniyet & & & 0,834 & & & 0,782 \\
\hline E-Sadakat & & & 0,839 & & & 0,624 \\
\hline
\end{tabular}

Son olarak bireylerin bilgisayar ve cep telefonu kullanma sıklılıklarının araştırma modeli üzerinde düzenleyici bir rolünün bulunup bulunmadı̆̆ı araştırılmıştır. Kullanım sıklıklarının araştırma modeli üzerinde herhangi bir düzenleyici etkisinin olmadığı tespit edilmiştir.

\section{Sonuç}

İşletmeden tüketiciye e-ticaret, tüketicilerin internet vasıtasıyla işletmelerden doğrudan mal ve hizmet satın alabilmeleri anlamına gelmektedir. E-ticaretin önemli bileşenlerinden biri olan e-ticaret pazaryerleri ise, çok sayıda alıcı ve satıcıyı buluşturan çevrim içi mağazalardır. Tüketiciler birçok farklı e-ticaret pazaryerine oldukça kısa bir süre içinde ulaşabilmektedirler. E-ticaret pazaryerlerindeki işlem hacminin artması mevcut müşterilerin kaybedilmemesiyle ve sürekli aynı web sitesini ziyaret eden, tekrarlayan satın alımlar yapan ve e-ticaret pazaryerlerine içtenlikle bağlı sadakatli müşterilerin varlığı ile gerçekleşebilmektedir. Buna göre müşterilerin e-sadakati ve e-ticaret işletmelerinin finansal performansı arasında güçlü bir ilişki bulunduğu ileri sürülmektedir (Harris \& Goode, 2004).

E-ticarette uzun vadede başarıya ulaşabilmek için e-sadakatin gerekliliğini ileri süren bu araştırmada e-ticaret pazaryerlerine yönelik müşteri sadakatini (e-sadakati) etkileyen; eağızdan ağıza iletişim (e-WOM), icra etme/gerçekleştirme, güvenlik/gizlilik, müşteri hizmetleri, web tasarımı, ün/tanınırlık, e-güven, e-memnuniyet değişkenlerinin direkt ve dolaylı etkileri ve cinsiyetin rolü araştırılmıştır.

Araştırma sonuçlarına göre e-ticaret pazaryerindeki kullanıcıların oyları, değerlendirme puanları, yorumları, tavsiyeleri e-ticaret pazaryerlerinin bilinirliğinin/ününün/tanınırlığının artmasını sağlamaktadır. E-ticaret pazaryerindeki ürünlerin doğru tanıtılması ve zamanında teslim edilmesi e-ticaret pazaryerlerine duyulan güveni artırmaktadır. Doğru ürünler, 
vaadedildikleri gibi teslim edildiğinde e-ticaret pazaryerlerine olan güven çoğalmaktadır. Eticaret pazaryerlerinin gizliliğe önem vermesi ve veri güvenliğini sağlaması e-ticaret pazaryerlerine yönelik olan güveni arttırmaktadır. Veri güvenliği e-pazaryerine yönelik güvenin önemli koşullarından biri olarak görülebilmektedir. Bir web sitesindeki kişisel veriler korunmadan o websitesindeki güvenlikten bahsedilememektedir. E-ticaret pazaryerlerinin zaman kaybı oluşturmayacak ve işlemlere dair detaylı bilgi sunacak şekilde tasarlanması eticaret pazaryerine ve alışveriş deneyimine yönelik memnuniyetin artmasına yol açmaktadır. Eticaret pazaryerlerinin iyi dizayn edilmesi müşterilerin deneyimleri olumlu etkilemekte ve memnuniyete yol açmaktadır. Web sitesinin ünlü, tanınır ve bilinir olması e-ticaret pazaryerlerine yönelik güvenin artmasına sebep olmaktadır. E-ticaret pazaryerinin ismine aşina olunduğunda, tanınırlık durumu tüketicilerde güven duygusunun oluşmasına yol açmaktadır. E-ticaret pazaryerlerine güven duyulması bu siteye yönelik memnuniyeti ve müşterilerin eticaret pazaryerlerine yönelik sadakatini arttırmaktadır. Güven tüketiciler için en önemli bileşenlerden biridir. E-ticaret pazaryerlerine yönelik oluşan memnuniyet duygusu, müşterilerin e-ticaret pazaryerlerine olan bağlılıklarını/sadakatlerini arttırmaktadır. Memnuniyet yaşan tüketiciler e-ticaret pazaryerlerinin sadık müşterileri olmaktadırlar.

Müşterilerin sorunlarının hızla ve samimi bir şekilde çözülüyor olması e-ticaret pazaryerlerine duyulan güveni ve memnuniyeti etkilememektedir. Bu durumun sebebi müşterilerin sorun yaşamadıkları zamanlarda da e-ticaret pazaryerlerine güven duyabilmeleri ve memnuniyet duygusu yaşayabilmeleri olarak açıklanabilmektedir.

E-ticaret pazaryerlerindeki kullanıcıların oyları, değerlendirme puanları, yorumları, tavsiyelerinin varlığı e-ticaret pazaryerine olan güven duygusunu etkilememektedir. Bir eticaret pazaryerinde yorumların ve puanlamaların bulunması tüm bu değerlendirmelerin doğru olduğu anlamına gelmemektedir. Kötü yorumların silinmiş ve değerlendirmelerin satın alınmış olma ihtimali bulunmaktadır. Buna göre değerlendirmeler etkisini yitirmiş olabilmektedir.

E-ticaret pazaryerlerinin veri güvenliğine önem vermesi ve istenilen ürünlerin doğru ve zamanında teslim edilmesi müşterilerin e-pazaryerlerine yönelik oluşan memnuniyetlerini etkilememektedir. Bu özelliklerin e-ticaret pazaryerlerinin var oluşları için birer gereklilik olduğu ve tüketiciler tarafından zorunlu özellikler olarak görüldükleri ve memnuniyete etki etmedikleri ancak söz konusu özelliklere sahip olmamanın tüketiciler için bir sorun oluşturacağ düşünülmektedir.

Erkek ve kadın gruplarında görülen farklılıklar şöyle sıralanabilmektedir. Erkek grubunda kişisel mahremiyet/veri güvenliği ve e-ticaret pazaryerlerinin tanınırlığı, e-ticaret pazaryerlerine olan güveni etkilememektedir. Yalnızca ürünlerin doğru tanıtılması, doğru 
ürünün gelmesi ve zamanında teslimat olduğunda erkek grubu e-ticaret pazaryerlerine güven duymaktadır. $\mathrm{Bu}$ durum erkek gruplarının alışverişilerini yalnızca güvenli bir şekilde tamamlayabildikten sonra e-ticaret sitesine güven duyabileceklerine işaret etmektedir.

Kadın gruplarında ise işlemleri kolay, hızlı ve yeteri derecede bilgi alarak tamamlamak e-ticaret sitesine yönelik olan memnuniyete etki etmemektedir. Bir diğer ifadeyle kadınların eticaret web sitesinden memnun olabilmeleri websitesinin teknik özelliklerine bağlı değildir. Bu ise kadın gruplarının genellikle sonuç odaklı ve duygusal yapıları ile uyumludur. Kadın grubunda e-ticaret pazaryerine güven duyulması kadınların e-ticaret pazaryerine sadakatlerini etkilememektedir. Kadınların e-ticaret pazaryerine sadık olabilmeleri için yaşadıkları alışveriş deneyimlerinden memnun olmaları yeterlidir. Kadınların sadece ürünlerden, web sitesinden ve alışveriş deneyiminden memnun olunması kolaylıkla e-ticaret pazaryerine yönelik sadakati doğuracaktır.

E-ticaret pazaryerlerinin ünü/tanınırlığı, e-ticaret pazaryerlerine duyulan güven ve eticaret pazaryerlerine yönelik oluşan memnuniyetin varyansları kadın ve erkek gruplarında benzer oranlarda açıklanmaktadır. Ancak kadın gruplarında e-ticaret pazaryerlerine yönelik sadakat duygusunun varyansı, erkeklere göre daha az açıklanmaktadır. Bu bulgu ise kadınların sadakat duygusuna etki eden ve bu çalışmada ele alınmamış başka değişkenler olduğuna işaret edebilmektedir.

İlerideki çalışmalarda kadınların e-ticaret sitelerine yönelik sadakatleri üzerinde etkisi olabilecek ve alanyazında yer alan farklı değişkenler eklenerek e-ticaret pazaryerlerine yönelik sadakatlerinin varyansının açıklanma düzeyinin arttırılması tavsiye edilmektedir. Ayrıca karma yöntem veya nitel bir yöntem kullanılarak bu çalışmadaki araştırma yönteminin kapsamının genişletilmesi tavsiye edilmektedir. İlerideki araştırmaların da Türkiye örneklemi üzerinde gerçekleştirilmesi ilgili literatüre katkıda bulunacaktır.

\section{KAYNAKÇA}

Al-Adwan, A. S., \& Al-Horani, M. A. (2019). Boosting customer e-loyalty: An extended scale of online service quality. Information (Switzerland), 10(12), 1-27.

Al-Dweeri, R. M., Moreno, A. R., Montes, F. J. L., Obeidat, Z. M., \& Al-Dwairi, K. M. (2018). The effect of e-service quality on Jordanian student's e-loyalty: an empirical study in online retailing. Industrial Management \& Data Systems, 119(4), 902-923.

Alam, S. S., \& Yasin, N. M. (2010). An investigation into the antecedents of customer satisfaction of online shopping. Journal of Marketing Development and Competitiveness, 5(1), 71-78.

Anderson, R. E., \& Srinivasan, S. S. (2003). E-satisfaction and e-loyalty: a contingency framework. Psychology and Marketing, 20(2), 123-138. 
Awad, N. F., \& Ragowsky, A. (2008). Establishing trust in electronic commerce through online word of mouth: An examination across genders. Journal of Management Information Systems, 24(4), 101-121.

Brislin, R. W., Lonner, W. J., \& Thorndike, R. M. (1973). Cross-cultural research methods (Vol. 11). New York: J. Wiley.

Bulut, Z. A., \& Karabulut, A. N. (2018). Examining the role of two aspects of eWOM in online repurchase intention: An integrated trust-loyalty perspective. Journal of Consumer Behaviour, 17(4), 407-417.

Butt, M. M., Yingchen, Y., Mohd-Any, A. A., Mutum, D. S., Ting, H., \& Wei, K. K. (2018). Antecedents of consumer-based electronic retail brand equity: An integrated model. Asian Academy of Management Journal, 23(2), 69-99.

Cai, S., \& Xu, Y. (2006). Effects of outcome, process and shopping enjoyment on online consumer behaviour. Electronic Commerce Research and Applications, 5(4), 272-281.

Çetin, F., \& Basım, H. N. (2012). Örgütsel psikolojik sermaye: bir ölçek uyarlama çalışması. Amme Idaresi Dergisi, 45(1), 121-137.

Chan, Y. Y. Y., \& Ngai, E. W. T. (2011). Conceptualising electronic word of mouth activity: An input-process-output perspective. Marketing Intelligence and Planning, 29(5), 488-516.

Chek, Y. L., \& Ho, J. S. Y. (2016). Consumer electronics e-retailing: Why the alliance of vendors' e-service quality, trust and trustworthiness matters. In Procedia - Social and Behavioral Sciences, 219, 804-811.

Collier, J. E., \& Bienstock, C. C. (2006). Measuring service quality in e-retailing. Journal of Service Research, 8(3), 260-275.

Cristobal, E., Flavián, C., \& Guinalíu, M. (2007). Perceived e-service quality (PeSQ): Measurement validation and effects on consumer satisfaction and web site loyalty. Managing Service Quality, 17(3), 317-340.

Cyr, D. (2008). Modeling web site design across cultures: Relationships to trust, satisfaction, and E-Loyalty. Journal of Management Information Systems, 24(4), 47-72.

Cyr, D., Head, M., \& Larios, H. (2010). Colour appeal in website design within and across cultures: A multi-method evaluation. International Journal of Human Computer Studies, 68(1-2), 121.

Devaraj, S., Fan, M., \& Kohli, R. (2002). Antecedents of B2C channel satisfaction and preference: Validating e-commerce metrics. Information Systems Research, 13(3), 316-333.

Eastlick, M. A., Lotz, S. L., \& Warrington, P. (2006). Understanding online B-to-C relationships: An integrated model of privacy concerns, trust, and commitment. Journal of Business Research, 59(8), 877-886. 
Fang, J., Shao, Y., \& Wen, C. (2016). Transactional quality, relational quality, and consumer eloyalty: Evidence from SEM and fsQCA. International Journal of Information Management, 36(6), 1205-1217.

Fu, X., Zhang, B., Xie, Q., Xiao, L., \& Che, Y. (2011). Impact of quantity and timeliness of ewom information on consumer's online purchase intention under C2C environment. Asian Journal of Business Research, 1(2), 37-52.

Garbarino, E., \& Johnson, M. S. (1999). The different roles of satisfaction, trust, and commitment in customer relationships. Journal of Marketing, 63(2), 70-87.

Giovanis, A. N. Athanasopoulou, P. (2014). Gaining customer loyalty in the e-tailing marketplace: the role of e-service quality, e-satisfaction and e-trust. International Journal of Technology Marketing 6, 9(3), 288-304.

Gong-min, Z. (2010). Research on customer loyalty of B2C e-commerce. In China-USA Business Review, 9, 1-61.

Gounaris, S., Dimitriadis, S., \& Stathakopoulos, V. (2010). An examination of the effects of service quality and satisfaction on customers' behavioral intentions in e-shopping. Journal of Services Marketing, 24(2), 142-156.

Gummerus, J., Liljander, V., Pura, M., \& Van Riel, A. (2004). Customer loyalty to content-based Web sites: The case of an online health-care service. Journal of Services Marketing, 18(3), $175-186$.

Gürbüz, S. (2019). AMOS ile yapısal eşitlik modellemesi. Ankara: Seçkin Yayınc1lık.

Hair, J. F., Black, W. C., Babin, B. J., Anderson, R. E., \& Tatham, R. L. (2006). Multivariate data analysis (6th Edition). New Jersey: Prentice Hall.

Harris, L. C., \& Goode, M. M. H. (2004). The four levels of loyalty and the pivotal role of trust: a study of online service dynamics. Journal of Retailing, 80(2), 139-158.

Hennig-Thurau, T., \& Walsh, G. (2003). Electronic word-of-mouth: Motives for and consequences of reading customer articulations on the internet. International Journal of Electronic Commerce, 8(2), 51-74.

Husain, S. (2017). The determinants of loyalty in online commerce-an exploratory study in India. Electronic Journal of Information Systems in Developing Countries, 81(7), 1-17.

Jin, B., \& Park, J. Y. (2006). The moderating effect of online purchase experience on the evaluation of online store attributes and the subsequent impact on market response outcomes. Advances in Consumer Research, 33, 203-211.

Kassim, N., \& Abdullah, N. A. (2010). The effect of perceived service quality dimensions on customer satisfaction, trust, and loyalty in e-commerce settings A cross cultural analysis. Asia Pacific Journal of Marketing and Logistics, 22(3), 351-371. 
Kim, J. H., \& Kim, C. (2010). E-service quality perceptions: A cross-cultural comparison of american and Korean consumers. Journal of Research in Interactive Marketing, 4(3), 257275.

Kim, Jinwoo, \& Lee, J. (2002). Critical design factors for successful e-commerce systems. Behaviour \& Information Technology, 21(3), 185-199.

Kim, Jiyoung, Jin, B., \& Swinney, J. L. (2009). The role of etail quality, e-satisfaction and e-trust in online loyalty development process. Journal of Retailing and Consumer Services, 16(4), 239-247.

Kılıç, A. F., \& Koyuncu, İ. (2017). Ölçek uyarlama çalışmalarının yapı geçerliği açısından incelenmesi. In Küreselleşen dünyada ĕ̆itim. 415-438.

Kline, R. B. (2011). Principle and practice of structural equation modelling (3th Press). New York, NY: The Guilford Press.

Kline, R. B. (2016). Principle and practice of structural equation modelling (4th Press). New York, NY: The Guilford Press.

Konradt, U., Wandke, H., Balazs, B., \& Christophersen, T. (2003). Usability in online shops: Scale construction, validation and the influence on the buyers' intention and decision. Behaviour and Information Technology, 22(3), 165-174.

Kurt, G. (2013). E-perakendecilik etiği ve müşteri sadakati arasındaki ilişki: Algılanan güven ve algılanan memnuniyetin aracı rolü. Internet Uygulamaları ve Yönetimi Dergisi, 4(2), 49-68.

Lee, G. G., \& Lin, H. F. (2005). Customer perceptions of e-service quality in online shopping. International Journal of Retail and Distribution Management, 33(2), 161-176.

Leonnard. (2019). Exploring the relationship among e-service quality, loyalty at higher education institutions. Journal on Efficiency and Responsibility in Education and Science, 12(4), 103110.

Li, H., Tevrizci, C., \& Aham-Anyanwu, N. (2014). An empirical study of e-loyalty development process from the e-service quality experience: Testing the etailq scale. In Proceedings - Pacific Asia Conference on Information Systems, PACIS 2014.

Liu, D., \& Guo, X. (2017). Can trust and social benefit really help? Empirical examination of purchase intentions for wearable devices. Information Development, 33(1), 43-56.

López-Miguens, M. J., \& Vázquez, E. G. (2017). An integral model of e-loyalty from the consumer's perspective. Computers in Human Behavior, 72, 397-411.

Malakmadze, K., Ünver, S., \& Arıkan, E. (2017). Çevrimiçi gizlilik ve e-sadakat eğilimi ilişkisi üzerine ülkeler arası bir inceleme: Türkiye ve Rusya arasında bir karşılaştırma. Journal of Business Research - Turk, 9(1), 439-463.

McCole, P. (2002). The role of trust for electronic commerce in services. International Journal of 
Contemporary Hospitality Management, 14(2), 81-87.

Mcknight, H. D., Kacmar, C. J., \& Choudhury, V. (2004). Shifting factors and the ineffectiveness of third party assurance seals: a two-stage model of initial trust in a web busines. Electronic Markets, 14(3), 1-15.

Miyazaki, A. D., \& Fernandez, A. (2001). Consumer perceptions of privacy and security risks for online shopping. Journal of Consumer Affairs, 35(1), 27-44.

Omar, M. W. (2009). The mediating effect of cognitive and emotional satisfaction on customer loyalty. International Journal of Management Innovation Systems, 1(2), 1-13.

Parasuraman, A., Zeithaml, V. A., \& Malhotra, A. (2005). E-S-QUAL a multiple-item scale for assessing electronic service quality. Journal of Service Research, 7(3), 213-233.

Pavlou, P. A., Liang, H., \& Xue, Y. (2007). Understanding and mitigating uncertainty in online environments: a principal-agent perspective. MIS Quarterly, 31(1), 105-136.

Pitta, D., Franzak, F., \& Fowler, D. (2006). A strategic approach to building online customer loyalty: Integrating customer profitability tiers. Journal of Consumer Marketing, 23(7), 421429.

Porter, M. E. (2001). Strategy and the Internet. Harvard Business Review, 20, 62-78.

Quan, S. (2010). Assessing the effects of e-service quality and esatisfaction on internet banking loyalty in China. In Proceedings of the International Conference on E-Business and EGovernment, ICEE 2010 (pp. 93-96). IEEE.

Reichheld, F. F., \& Reprint, P. S. (2000). E-loyalty: your secret weapon on the web. Harvard Business Review, 78(4), 105-113.

Ribbink, D., Van Riel, A. C. R., Liljander, V., \& Streukens, S. (2004). Comfort your online customer: Quality, trust and loyalty on the internet. Managing Service Quality: An International Journal, 14(6), 446-456.

Rodríguez, P. G., Villarreal, R., Valiño, P. C., \& Blozis, S. (2020). A PLS-SEM approach to understanding E-SQ, E-Satisfaction and E-Loyalty for fashion E-Retailers in Spain. Journal of Retailing and Consumer Services, 57, 102201.

Safa, N. S., \& Ismail, M. A. (2013). A customer loyalty formation model in electronic commerce. Economic Modelling, 35, 559-564.

Sai Vijay, T., Prashar, S., \& Sahay, V. (2019). The influence of online shopping values and web atmospheric cues on e-loyalty: Mediating role of e-satisfaction. Journal of Theoretical and Applied Electronic Commerce Research, 14(1), 1-15.

Santos, J. (2003). E-service quality: A model of virtual service quality dimensions. Managing Service Quality: An International Journal, 13(3), 233-246.

See-to, E. W. K., \& Ho, K. K. W. (2014). Value co-creation and purchase intention in social network 
sites: The role of electronic Word-of-Mouth and trust - A theoretical analysis. Computers in Human Behavior, 31, 182-189.

Semeijn, J., van Riel, A. C. R., van Birgelen, M. J. H., \& Streukens, S. (2005). E-services and offline fulfilment: How e-loyalty is created. Managing Service Quality, 15(2), 182-194.

Sevim, N. (2018). Çevrimiçi e-müşteri sadakatinin oluşumunda e-hizmet kalitesi, e-güven ve etatminin etkisi. Business \& Management Studies: An International Journal, 6(1), 107-127.

Shankar, V., Smith, A. K., \& Rangaswamy, A. (2003). Customer satisfaction and loyalty in online and offline environments. International Journal of Research in Marketing, 20(2), 153-175.

Şimşek, Ö. F. (2007). Yapısal Eşitlik Modellemesine Giriş: Temel İlkeler ve LISREL Uygulamaları. Ankara: Ekinoks Yayınları.

Singh, J., \& Sirdeshmukh, D. (2000). Agency and trust mechanisms in consumer satisfaction and loyalty judgments. Journal of the Academy of Marketing Science, 28(1), 150-167.

Sirdeshmukh, D., Singh, J., \& Sabol, B. (2002). Consumer trust, value, and loyalty in relational exchanges. Journal of Marketing, 66(1), 15-37.

Sivakumaran, B., Auburn, L. C. S., \& Maheswarappa, S. S. (2014). Trust-commitment in ecommerce: A cross-cultural exploration. Great Lakes Herald, 8(2), 65-93.

Social We Are (2020). Digital in 2020. Erişim adresi: https://wearesocial.com/digital-2020

Szymanski, D. M., \& Hise, R. T. (2000). E-satisfaction: An initial examination. Journal of Retailing, 76(3), 309-322.

Teo, T. S. H., \& Liu, J. (2007). Consumer trust in e-commerce in the United States, Singapore and China. Omega, 35(1), 22-38.

T.C. Ticaret Bakanlığı (2020a). İstatistikler. Erişim adresi: https://www.eticaret.gov.tr/istatistikler

T.C. Ticaret Bakanlığı (2020b). E-ticaret akademisi: pazaryeri açma. Erişim adresi: https://www.eticaret.gov.tr/cevrimiciegitim/pazaryeri-magaza-acma-68

Torres-Moraga, E., Vásquez-Parraga, A. Z., \& Barra, C. (2010). Antecedents of donor trust in an emerging charity sector: The role of reputation, familiarity, opportunism and communication. Transylvanian Review of Administrative Sciences, 6(29), 159-177.

Toufaily, E., Ricard, L., \& Perrien, J. (2013). Customer loyalty to a commercial website: Descriptive meta-analysis of the empirical literature and proposal of an integrative model. Journal of Business Research, 66(9), 1436-1447.

Tran, L. T. T., Pham, L. M. T., \& Le, L. T. (2019). E-satisfaction and continuance intention: The moderator role of online ratings. International Journal of Hospitality Management, 77, 311322.

Urban, G. L., Sultan, F., \& Qualls, W. J. (2000). Placing trust at the center of your internet strategy. MIT Sloan Management Review, 42(1), 39-48. 
Verhoef, P. C., Franses, P. H., \& Hoekstra, J. C. (2002). The Effect of relational constructs on customer referrals and number of services purchased from a multiservice provider: Does age of relationship matter? Journal of the Academy of Marketing Science, 30(3), 202-216.

Vos, A., Marinagi, C., Trivellas, P., Eberhagen, N., Skourlas, C., \& Giannakopoulos, G. (2014). Risk reduction strategies in online shopping: E-trust perspective. Procedia - Social and Behavioral Sciences, 147, 418-423.

Wallace, D. W., Giese, J. L., \& Johnson, J. L. (2004). Customer retailer loyalty in the context of multiple channel strategies. Journal of Retailing, 80(4), 249-263.

Wang, R., Wang, S., Wu, T., \& Zhang, X. (2012). Customers E-trust for online retailers: A case in China. In 2012 Eighth International Conference on Computational Intelligence and Security Customers (pp. 573-577). IEEE.

Wolfinbarger, M., \& Gilly, M. C. (2003). eTailQ: dimensionalizing, measuring and predicting etail quality. Journal of Retailing, 79, 183-198.

Yaşin, B., Özkan, E., \& Baloğlu, S. (2017). Tüketicilerin çevrimiçi perakende alışveriş sitelerine yönelik sadakatleri üzerinde memnuniyet, güven ve kalite algılarının rolü. İstanbul Üniversitesi İsletme Fakültesi İ̧sletme İktisadı Enstitüsü Yönetim Dergisi, 28(83), 24-47.

Yazıcıoğlu, Y., \& Erdoğan, S. (2004). SPSS uygulamalı bilimsel araştırma yöntemleri. (D. Yayıncılık, Ed.). Ankara.

Yıldı, S., \& Karadirek, G. (2014). Elektronik hizmet kalitesi algılamaları: bireysel internet bankacılığı kullanıcıları üzerine bir uygulama. Gümüşhane Üniversitesi Sosyal Bilimler Elektronik Dergisi, 10, 304-329.

Yoo, C. W., Sanders, G. L., \& Moon, J. (2013). Exploring the effect of e-WOM participation on eLoyalty in e-commerce. Decision Support Systems, 55(3), 669-678.

Zheng, X., Lee, M., \& Cheung, C. M. K. (2017). Examining e-loyalty towards online shopping platforms: The role of coupon proneness and value consciousness. Internet Research, 27(3), $709-726$. 